\title{
Comonentary
}

\section{The third dimension: How fire-related research can advance ecology and evolutionary biology}

\author{
Byron B. Lamont and Tianhua He
}

Byron B. Lamont (B.Lamont@curtin.edu.au), School of Molecular and Life Sciences, Curtin University, PO Box U1987, Perth, WA 6845, Australia

Tianhua He, College of Science, Health, Engineering and Education, Murdoch University, Murdoch, WA 6150, Australia

\begin{abstract}
Most of the Earth's vegetated surface is fireprone but the relevance of fire in understanding how nature works is not always recognized. We aim to show that, by adding the fire dimension to observations on biological phenomena, interpretations can be improved; how fire-related research can be used to answer 'fundamental' questions in ecology; and how theories/models developed for fireprone ecosystems can be applied to advancing disturbance ecology, biogeography and evolutionary biology more generally. We compiled lists from the world-wide web of the most highly cited papers in fire ecology, and examined papers that had been approached from multiple viewpoints, including fire. We show that great advances over the last 20 years have been made in our understanding of the pivotal role of fire as a driver of many ecological processes and a powerful selective agent/evolutionary trigger among biota. We document 21 sets of observations originally interpreted in the context of the two traditional dimensions, prevailing environment and biotic interactions, but can also be shown to have a strong, if not dominant, historical link to fire. We note that fire-related research is able to address 55 of the 100 questions considered 'fundamental' in ecology and that many have already received some attention in fireprone ecosystems. We show how theories/ models that had their origins in fireprone systems can be applied to other disturbance-prone systems and thus have wide application in ecology and evolutionary biology. Fire and other disturbances should be included as variables in research about possible critical environmental and biotic constraints controlling ecosystem function in general. Adding this third dimension to research endeavours greatly enriches our understanding of how nature works at the global scale in an era where ecosystems are
\end{abstract}

changing rapidly and novel species-environmental interactions are emerging.

Keywords: evolutionary processes, fire-driven evolution, fire ecology, fundamental ecological questions, natural disturbances

\footnotetext{
"Fire is a natural process that is as fundamental to ecosystems as rain and the sun and (thus) we need a theory that rises out of this fact." (Pyne 2016)
}

\section{Introduction}

Traditionally, the distribution and associated traits of plants over the Earth's terrestrial surface have been interpreted in terms of abiotic environmental constraints (essentially climate, soils, topography) and biotic interactions (pollination, herbivory, diseases, competition). The third dimension/component, disturbance (especially fire), has often received less attention or even been ignored (Pausas and Bond 2019). For example, among the 100 papers published in journals of the British Ecological Society (BES) and considered most influential by the editors (Grubb and Whittaker 2014), only one (Lavorel and Garnier 2002) cites fire or heat. In accompanying commentaries on these papers, the generic term, disturbance, is raised five times but there is no mention of fire, whereas other environmental constraints (such as soil, nutrients, water, climate, temperature and plant-animal interactions) are mentioned many times. But it would be premature to conclude from this report that fire is not an active field of research, nor that it is only a minor environmental force with limited relevance to 


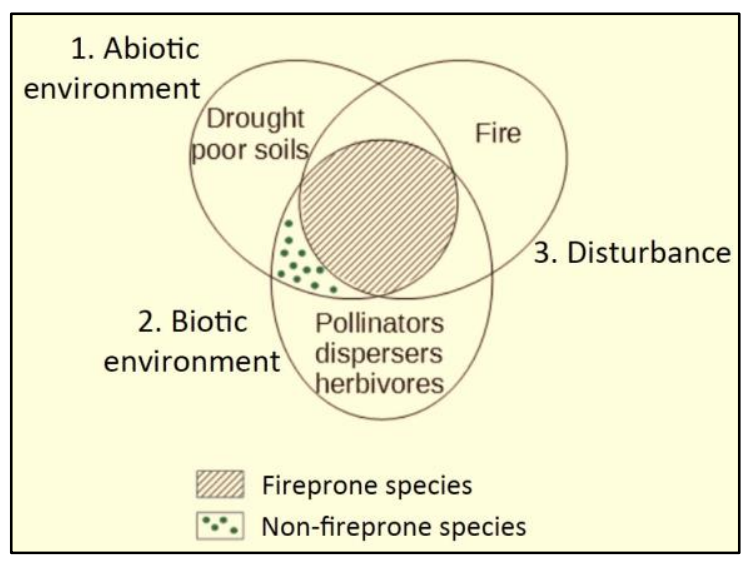

Figure 1. Venn diagram showing how the three dimensions of environmental constraints interact to control the ecology and evolution of the Earth's terrestrial biota, with non-fireprone species limited in abundance by comparison. Examples of possible constraints have been added to the zone of influence of each dimension. Adapted from Pausas and Lamont (2018).

explaining ecological processes. On feeding in the key words "fire" (for the paper title) and "ecology" (to identify the journal) into Google Scholar, of the first 1,000 BES papers that appeared, we noted that a substantial 206 papers dealing with fire were published in BES journals, but apparently they must lack 'influence'. We propose that disturbance/ perturbations, especially fire, should be raised to equal status with abiotic and biotic constraints as controlling the ecology and evolution of plants and animals across the Earth's terrestrial surface (Figure 1).

Fires have burned on Earth ever since the evolution of terrestrial plants 420 million years ago (Glasspool et al. 2004), and subsequently have had profound impacts on the Earth system (Bowman et al. 2009, Archibald et al. 2018). Currently, most of the Earth's vegetated surface is fireprone, and on average $5 \%$ of the Earth's vegetated surface is burnt every year, and $60 \%$ over any given 15 -year period (Archibald et al. 2013). Great advances over the last 20 years have been made in our understanding of the pivotal role of fire as a driver of many ecological and Earth processes and as a powerful selective agent/evolutionary trigger among biota (Bond et al. 2005, Bowman et al. 2009, He and Lamont 2018a, $\mathrm{He}$ et al. 2019). Fires affect Earth system processes through altering the structure and composition of ecosystems (Pausas and Keeley 2009), controlling the distribution and diversity of biomes (Bond et al. 2005, Pausas and Ribeiro 2017), and shaping the evolution of functional traits (Keeley et al. 2011, Lamont et al. 2019a). Emissions from fire affect the cycling of carbon, phosphorus, and nitrogen (Wang et al. 2015, Wittkuhn et al. 2017). Fires alter the Earth's surface energy budgets and regional to global climate through increasing the land surface albedo, and emissions of greenhouse gases, aerosols and particulates (Randerson et al. 2006). Recently, Pausas and Lamont (2018) demonstrated how the inclusion of fire as a variable (the third dimension) greatly improved understanding of the distribution of the iconic plant family, Proteaceae, across Australia by taking the presence of fireproneness of the vegetation, as well as the other two dimensions, into account.

Here, we show that a) not only has fire-related research produced a suite of theories/models that can be applied throughout the fireprone regions of the world but also b) these theories have generality for relatively fire-free regions as well, especially those prone to disturbances other than fire. These objectives are achieved through four approaches. The first is to collate highly cited papers with ecological/biological effects of fires as a major part of their subject matter that illustrate the many issues that fire research can encompass. The second is to review phenomena that were initially interpreted in a non-fire context, mainly climate and herbivory (the first two dimensions), and then, with further observations, shown to benefit from the inclusion of fire-related explanations. The third is to demonstrate that many key questions in ecology, biogeography and evolutionary biology originally raised in a nonfire context can be, and have been, addressed by fire ecologists. Finally, we note that fire is a particular type of disturbance/perturbation and consider how the theories/models resulting from fire-related research can be applied more broadly in scientific endeavours.

\section{Highly influential papers that included fire as a key part of their subject matter}

We compiled a list of 25 highly cited papers with fire effects as (one of) their foci (Appendix Table A1). We excluded papers that dealt just with the properties of fire, i.e., as an end in itself. With a total of 31,542 (Web of Science) and 52,134 (Google Scholar) citations, as of 10 July 2019, these show that papers based on fire ecology have been well received by the scientific community. The topic of fire in these papers covers a wide range of disciplines, from organic chemistry, species invasion ecology, ecosystem dynamics, soil science, biodiversity evolution, forestry and climate change science. This shows that fire-related research has wide applicability in ecology. The role of fire as an ecological and evolutionary driver of ecological processes has received much less attention and detailed research on fire as an evolutionary trigger and mutagenic agent have only begun to emerge during the last decade (Simon et al. 2009, Crisp et al. 2011, Lamont and He 2017, He and Lamont 2018b). It is papers such as these that enabled us to prepare a list of theories/models developed for fireprone systems that could be tested for their generality in other disturbance-prone systems (see below). We also note that the periodic lists of Current Titles in 
Table 1. Ranking of 21 paired sets of observations on botanical phenomena (Table A2) according to whether observed fire-related or non-fire-related constraints gave scientifically sounder explanations (five ranks) and the evolutionary sequence (three ranks) in which the fire-related and non-fire-related constraints occurred together with their interaction.

\begin{tabular}{lcccccc}
\hline & \multicolumn{6}{c}{ Importance of fire-related constraint relative to non-fire-related constraint } \\
\cline { 2 - 6 } Time of origin of fire-related & Unclear & Less & Equal & More & Replaces \\
constraint & $(1)$ & $(2)$ & $(3)$ & $(4)$ & Subtotal \\
\hline Before non-fire-related (1) & 0 & 0 & 0 & 8 & 6 & 14 \\
Same time or unclear (2) & 1 & 2 & 1 & 1 & 0 & 5 \\
After non-fire-related (3) & 0 & 0 & 1 & 1 & 0 & 2 \\
Subtotal & 1 & 2 & 2 & 10 & 6 & 21 \\
\hline
\end{tabular}

Wildland Fire (https://fireecologyjournal.org/ current-titles-in-wildland-fire, curated by Jason Greenlee) reached 118,000 publications by the end of 2019 with a mean listing per month of about 400 new publications, and 70 books published over the last five years. There can be no question that studies centred on fire are currently an area of exceptional activity, perhaps rivalled only by that on climate change.

Fire as an alternative explanation for understanding certain biological phenomena

We searched the literature for observations on plant traits and geography that have been interpreted in both a non-fire context, and, usually later, in a firerelated context. If this leads to possible bias, as suggested by a reviewer, then it is either because few research projects have considered all three dimensions as potentially relevant explanatory variables or because our literature search was inadequate. This yielded 21 paired sets of observations/interpretations supported by 65 studies (Appendix Table A2), i.e., no single study examined all three dimensions, with each research group approaching the topic from the perspective with which they felt 'comfortable' (Pausas and Lamont 2018). These dealt with five aspects of soil-stored seeds; two with plant-stored seeds; three with growth form; three with biogeographic traits, originally related to climate and/or soils; four with protective plant traits (biotic or abiotic); and three with aridityrelated traits. We then examined both sets of evidence and ranked the importance (weight of evidence in support) of the fire-related interpretation versus the non-fire-related interpretation as unclear, less, equal, more, or the latter could replace the former entirely.

We determined that the inclusion of fire as a variable provided a more likely explanation of the critical constraints for almost half of the phenomena we examined (Table 1). For these, non-fire related limiting factors have an ancillary role (Appendix Table A2). Climate (seasonal drought or heat waves) were secondary constraints in seven cases compared with fire, with an eighth, on the switch from $\mathrm{C} 3$ to
C4 grasses, partly relating to decreasing rainfall and temperatures, and lower carbon dioxide levels (Osborne 2008). Plant-consuming animals appear to have had a minor role in three cases, and landscape variability provides little insight into the ratio of firestimulated resprouters to nonsprouters in one case. Of most interest are the five cases where a firerelated explanation is sufficient to replace the earlier interpretation. Four included reference to climate, with two of these including plant-animal interactions, and a fifth involving scarification of hard seeds by soil processes (that proved to be ineffective, unlike fire heat). One is of particular interest, for this was a well-executed test of the proposal that a warming climate was responsible for the apparent upward shift of chaparral species in the Santa Rosa Mountains, California (Kelly and Goulden 2008). Schwilk and Keeley (2012) showed that it was an artefact of the differences in fire history of the sites (at least for the key fire-killed species that they were able to examine in detail).

Thus, it seems, for phenomena occurring in fireprone environments, that fire often has the more important role in explaining plant traits and distribution patterns when compared with those originally proposed. Nevertheless, a few phenomena are not essentially fire adaptive, with non-firerelated functions equally important in two cases, two less important, and one (highly flammable terpenoids that are also known to deter some herbivores) uncertain as to their principal function. Clearly, there is a need for simultaneous tests of the hypothesised relevant variables so that their relative contribution to explaining the phenomenon can be assessed. Distinguishing a high summer-temperature from a fire-heat effect on breaking seed dormancy (Moreira and Pausas 2012) provides one of the few examples of what is required.

Our analysis of the evolutionary sequence of the different possible constraints was less formal here as this topic has been comprehensively reviewed elsewhere (Lamont et al. 2019a,b and references therein). We used this background to show that 14 of the 16 cases where the phenomenon could essentially be explained by its relationship with fire (columns 4 and 5 in Table 1) that fireproneness also 
preceded the advent of the less critical constraints such as climate seasonality (as it affects plant phenology) or granivores (as they affect the need for seed protection). It was not possible to distinguish the timing of the presence of fire from other possible constraints in five cases. Thus, the presence of fire was associated with the origin of the highly firetolerant leptospermoid Myrtaceae, especially Eucalyptus, as an advanced trait over its immediate ancestors but it is unknown if the universally present terpenoids arose then as well or earlier (Crisp et al. 2011). The same is true for the timing of the critical selective agents for ant-attracting arils on seeds that ensure their burial (was the key selective agent increasing granivory or intensifying fire?), succulence, geophyty, finely divided foliage and plants with C4-type photosynthesis. It is clear that additional ancestral trait assignments (the techniques themselves need refining) are required on multiple hypothesised constraints to distinguish the timing at which they were imposed on clades (Lamont et al. 2019b).

\section{Scope for fire-related research to address key questions in ecology and evolution}

Looking to highlight priorities for future research in ecology, Sutherland et al. (2013) identified 100 'fundamental' questions. Such an objective is laudable provided it does justice to the three dimensions of environmental constraints in ecology and evolutionary biology. Regarding the third dimension, the closest is question 26 that asks, "What demographic traits determine the resilience of natural populations to disturbance and perturbation?" Since the word fire is not mentioned in the document we decided to check the literature to see to what extent fire-related research has been undertaken on any of the 'fundamental' questions asked by Sutherland. The authors might respond that the questions are generic (as did a colleague) so you would not expect such a specific process as fire to be mentioned. That response is hard to defend as processes such as dispersal (mentioned four times), disease, parasitism, mutualism, allelopathy, weather and human behaviour are all the subject of questions (why not fire effects?). Abiotic components of ecosystems are raised, such as soil, nutrients (including nitrogen and phosphorus), microbes (five times) and groundwater, and such ecosystems as marine, terrestrial, and freshwater are highlighted (why not fireprone?), and such traits or growth forms as body size, leaf area, grasses, woody plants, megafauna are noted (why not seed storage, resprouters, bark thickness...?).

We found that 55 of these questions have indeed been examined in the context of fire (Appendix Table A3). This showed that fire-related research is particularly suited to addressing questions that deal with the control of population and community dynamics, biodiversity, ecosystem functioning and evolutionary ecology, including adaptive responses to environmental change (Figure 2). We suggest that a more thorough literature research would show almost all of these questions have been given some attention in the past but all await thorough investigation even in fireprone systems. Thus, we need to add a further question (101): "What is (i.e., ecology), and has been (i.e., evolutionary biology), the significance of fire among the world's biota compared with other environmental constraints?" Addressing this question would include testing if the biota is non-fire-tolerant in non-fireprone systems as the null model. Demonstrating that particular dynamics can be attributed to disturbances other than fire is equally relevant. Even where fire tolerance is demonstrated by biota in non-fireprone systems it immediately returns to issues of possible exposure to fire during their phylogenetic history (Lamont and He 2017).

\section{Testing fire-related theories for their wider applicability in nature}

Fire ecology fits more generally into the discipline of disturbance ecology. This field encompasses resistance, avoidance and adaptive responses to damage, dieback or mortality due to the presence of any kind of natural or anthropogenic disturbance. This includes diseases and pests, drought, flooding, frost, ice or heat waves; lightning strikes; wind, hail or snow storm damage; abrasion from flying objects in hurricanes or rubbing by large animals; landslides, rock and falling trees; treefall gaps; mammal trampling and vertebrate digging; volcanic activity (barren rock substrates); prolonged cloudiness from volcanic activity, meteorite impact; earthquake damage; invasion by exotic species; scouring by fast moving water; creation of new substrates by retreating water bodies, lava flows, island emergence; and human-caused disturbances harvesting, herding; dryland salinity, landclearing; buildings, roads and rubble; and polluted air, water and soil.

We searched the fire ecology/evolution literature for apparent paradigms in this field of research and then examined the possible applicability of these more generally in ecology and evolutionary biology, at least in the context of disturbance ecology and disturbance-induced evolution. There are four options available for relating fire-centred research to more general ideas in ecology and evolution:

1. A given theory developed without considering fire effects could be tested for its generality in the context of fire

2. A given theory developed for fireprone systems could be tested for its generality in other disturbance-prone systems

3. A given theory developed for fireprone systems uniquely applies to them as the idea is based on the unique properties of fire, such as causing ignition or producing heat exceeding that possible from sunlight alone

4. A given theory developed for non-fireprone systems cannot apply to fireprone systems, 
such as pertaining to the unique properties of aquatic systems or succulent desert vegetation.

Our purpose here is to consider the first two options as they allow for the issue of generality to be explored (Figure 3). These all involve the interplay between inductive and deductive logic. For our purposes, early case studies are used to develop general theories/models either in fire-free (Figure $3 \mathrm{~A}$ ) or fireprone (Figure 3B) systems (induction, it consistently applies in the particular, so probably applies more generally). The questions raised in Sutherland et al. (2013) are at this stage in a research program. The case studies in fireprone systems that we cite (Table 2, Table A2) are an attempt to formulate a theory that applies to both disturbed and non-disturbed systems. The fire-free theory is tested in a fireprone system (deduction, if it applies generally, then it must apply in the particular) to confirm its generality. If it is shown not to apply (induction), then the theory is abandoned or modified (it is general, except for/provided...). Alternatively, theories/models are developed in fireprone systems and the challenge is now to see if they also apply more generally. These ideas are less likely to apply universally but are more likely to be relevant to disturbed systems. Thus, fire-related theories should have some generality.

We identified 20 theories/models developed in, and for, fireprone systems that have potential application in disturbance-prone systems more generally (Table 2). These theories/models have some parallels with the 55 'fundamental' ecological questions that we consider fire-related research can help address but our list gives much more prominence to evolutionary processes (Figure 2). Most are well-established paradigms in fire ecology, especially those related to the fitness function of firerelated traits (theories 2, 4-6, 9, 13, 18). Some have probably not been articulated before, mainly because they are too new to have matured into a widely accepted hypothesis through extensive (deductive) testing $(7,14-17,19,20)$. Some have yet to be couched solely in terms of fire. For example, Vanneste et al. (2014) attributed high levels of genome duplication close to the CretaceousPaleogene boundary to "severe disturbance events" but gave no details. However, we know that this was the close of one of the most flammable periods in the Earth's history - the fiery Cretaceous (Brown et al.

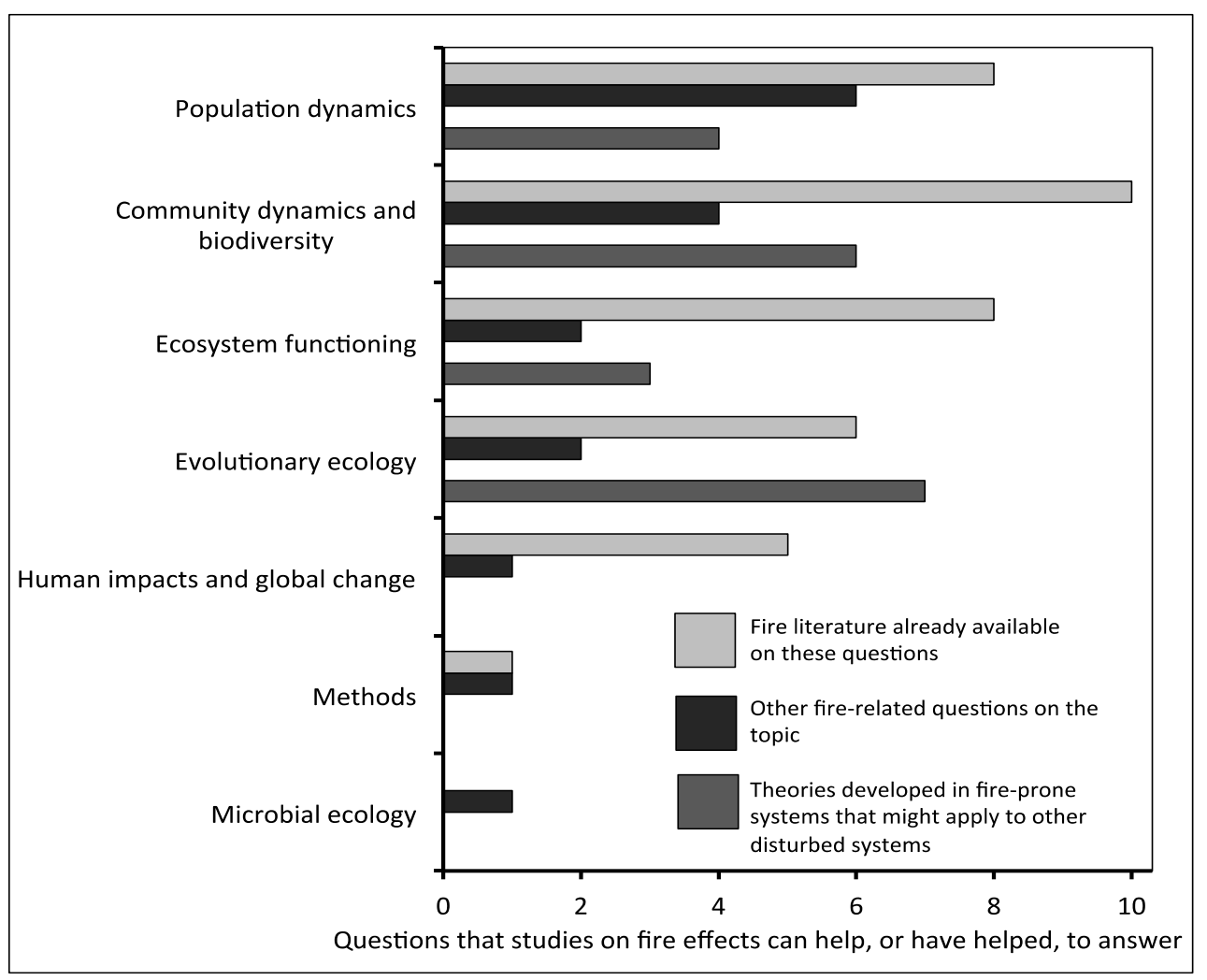

Figure 2. Collation of 55 'fundamental' ecological questions of the 100 compiled by Sutherland et al. (2013) that we show can be addressed in the context of fire effects (Table A3). Our survey shows that a number of these (twothirds) have already received some attention in the fire literature (light grey bars) and that a more thorough literature survey might show that some research has been undertaken on the remainder (black bars). No question has been examined exhaustively and fireprone systems are ideal settings for addressing many of them. In addition, we identified 20 theories/models derived from fire-related research (Table 2) and collated them here with the same headings as used for the ecological questions for comparative purposes (dark grey bars). 

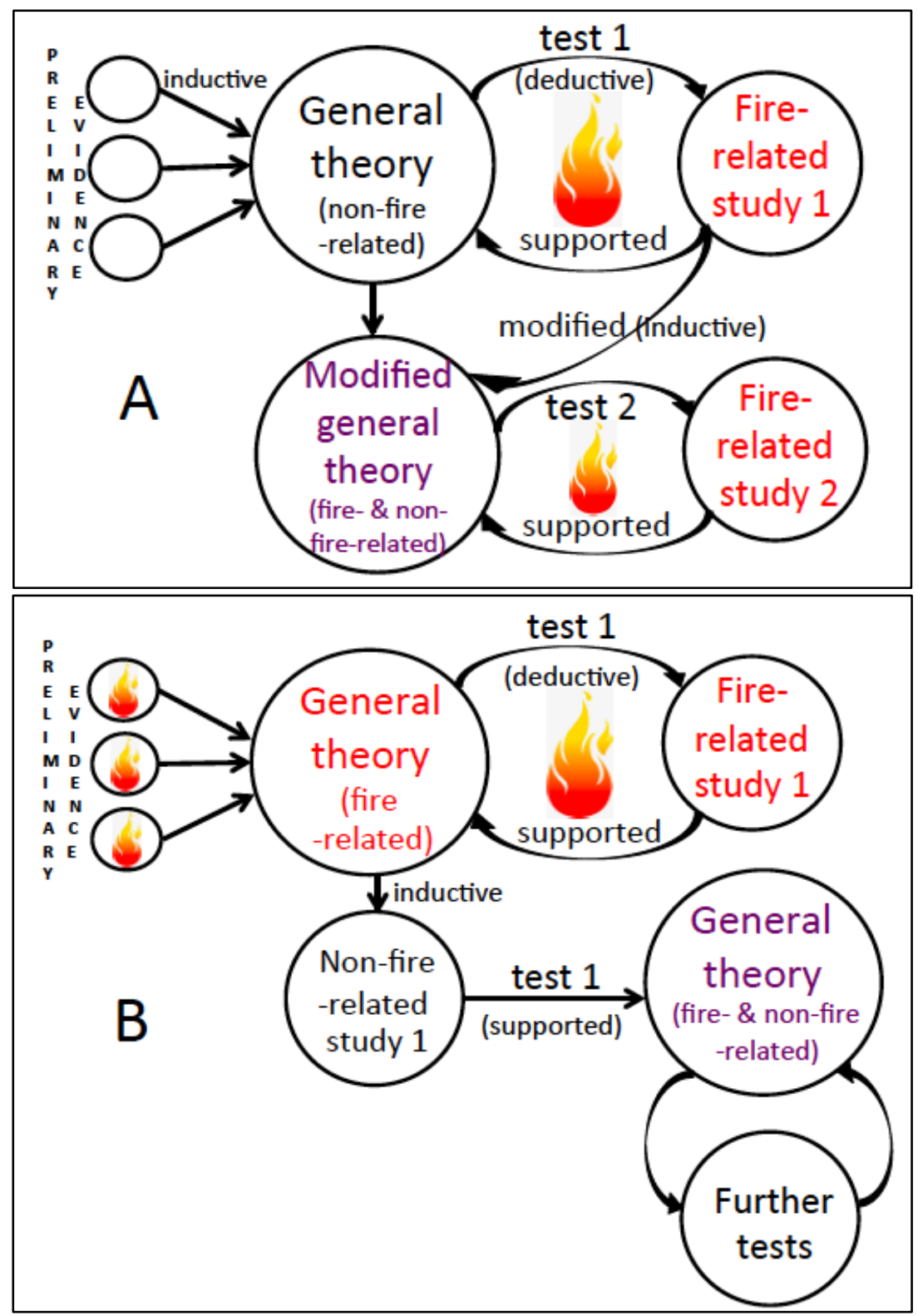

Figure 3. Procedures for testing the generality of theories and models developed initially for A) non-fireprone systems (to determine if they also apply to fireprone systems) and B) fireprone systems (to determine if they also apply to non-fireprone systems). It is most likely that systems that experience recurrent disturbance will conform with scenario B

2012, He et al. 2012). Moreover, there is much evidence of the ability of heat, ash, smoke particulates and firereleased volatiles to induce DNA mutations and polyploidisation in plants, bacteria and animals (Petterssen 1961, Pécrix et al. 2011, He and Lamont 2018b).

Our main purpose here has been to show that current fire-related theories/models may well be applied to other ecosystems, especially if they are disturbed on a recurrent basis. Much depends on the extent to which other disturbances can imitate fire properties (e.g. fire-mimicking, Lamont and He 2017) or fire effects. For example, disturbances that result in bare ground can be combined with a substantial soil-stored seed bank. This would only mimic the colonizing (patch-creating) property of fire, but not the cue for prolific germination. Greater exposure to sunlight, and thus a greater diurnal range of temperatures (Brits 1987), will promote dormancy breaking (Santana et al. 2013) but, as already noted, this would not be of the same order as under postfire conditions. Nevertheless, this scenario may promote synchronized germination and enable the testing of theories 1 and 9 (Table 2) under a variety of densities, species mixes and microsite sizes (Lamont et al. 1993).

Since there has been little theory development in other disturbance-prone systems, we essentially draw attention to the scope for comparing the effects of the wide array of disturbances that exist against our 20 fire-based theories/models in the search for generality (Table 2). In particular, we note what 


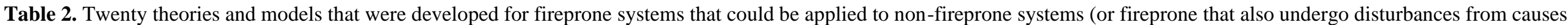
other than fire) to gauge their applicability and generality. Unless cited elsewhere in the text, references cited in this table are listed at the end of Appendix Table A3.

\begin{tabular}{ll}
\hline Theory developed in a fireprone context & $\begin{array}{l}\text { Supporting phenomena/literature from fireprone } \\
\text { systems }\end{array}$ \\
\hline $\begin{array}{l}\text { Population dynamics } \\
\begin{array}{l}\text { 1. Competition among seedlings is maximised } \\
\text { when their establishment is synchronised (i.e., } \\
\text { postfire), especially when serotiny/pyriscence } \\
\text { dominates the recovery pattern }\end{array}\end{array}$ & $\begin{array}{l}\text { Postfire microsite studies, Enright and Lamont (1989), } \\
\text { seedling thinning - Lamont et al. (1993) }\end{array}$ \\
$\begin{array}{ll}\text { 2. Heat tolerant/avoidance traits are adaptive } \\
\text { responses to recurrent high temperatures } \\
\text { (exceeding that possible via heat from sunlight) }\end{array}$ & $\begin{array}{l}\text { Seeds in fireprone systems are held in woody, heat- } \\
\text { resistant cones or fruits, or seeds are buried by ants } \\
\text { insulated by soil, buds are stored beneath thick bark or } \\
\text { belowground, Enright et al. (2007), Pausas et al. } \\
\text { (2018) }\end{array}$ \\
$\begin{array}{ll}\text { 3. Pyrophilic insects can detect fire and smoke } \\
\text { from great distances away (up to }>100 \mathrm{~km})\end{array}$ & $\begin{array}{l}\text { Pyrophilic Jewel beetles (Melanophila) have infrared } \\
\text { smoke detectors (Schütz et al. 1999) }\end{array}$
\end{tabular}

4. Seed storage in fireprone systems is a syndrome of traits that includes a) insulation from fire heat or heat tolerance, b) increased longevity mechanisms, c) responses to firerelated cues that break dormancy, and d)

protection from, or tolerance of, granivores, diseases, detritivores and ingestion by dispersal agents

Serotiny/pyriscence, hard-seededness/heat-stimulated germination, decay-resistant seeds with smokestimulated germination - reviewed in Lamont et al. (2019a)

Community dynamics and biodiversity

5. Fire (disturbance) induces ultimate responses that increase fitness via specialized survival and/or reproductive traits
Serotiny/pyriscence; fire-stimulated resprouting, flowering and germination (Lamont and Downes 2011, Causley et al. 2016, Pausas et al. 2018)

\section{What and how to test in non-fireprone systems} (e.g., treefall gaps), set up a trial that varies planting density possibly including enclosures in addition to controls to compare against herbivore effects

This hypothesis is uniquely applicable to fireprone systems. It would need to be completely modified to apply to particular disturbance types of interest. Thus the relevant tolerant/avoidance traits would refer to such constraints of interest as frost, severe winds, bare ground, trampling, flooding and it would be necessary to demonstrate a history of association with them over evolutionary time

Observe other animals (insects, birds, mammals) for movement and migration dynamics as a response to other disturbances that produce signals (visual, olfactory, auditory) to which they respond positively

Impose agents of disturbance on seeds produced by species native to disturbance-prone ecosystems (plus controls) and gauge their ability to survive. Test their ability to remain viable after decade-long periods of storage in soil, presence of pathogens and decomposers, ingestion by local granivores and omnivores. Impose dormancy-breaking cues likely to be encountered as a result of the disturbance (abrasion, waterlogging, lower or higher temperatures, pollutants...) and note effects on viability and post-treatment germination
Assess adaptive species traits that resist, avoid or respond to damage/dieback/ mortality due to presence of all types of disturbances (see main text for details) 
6. There is a dichotomy in responses to fire (disturbance) - either survival (resprouting) or mortality followed by recruitment of offspring

7. Pyrodiversity promotes biodiversity

8. "Initial floristic composition" model of community succession, also called "autosuccession"- the same biota are present immediately postfire (post-disturbance) as were present prefire (pre-disturbance) though the slopes and peaks of their abundance curves may not coincide

9. Species are cued to release or germinate their seeds in response to disturbance (i.e., postfire) as conditions for recruitment are optimal then. Corollary: lack of fire-stimulated germination occurs when the disturbance is so frequent that seed storage is redundant or maladaptive

10. Alternative vegetation states are mediated by fire, such that the types of vegetation and species now clothing the Earth would be quite different in the absence of fire
Wells (1969), Lamont and Wiens (2003), Pausas and Keeley (2014). [The model of Bellingham and Sparrow (2000) is in a wider context than fire]

Different fire events create patches varying greatly in size, structure, intensity and time since fire (He et al. 2019), the fire-maintained prairies of N America

(Martin and Spasis 1992), diversity of marsupials in

N. Australia (Davies et al. 2018)

Noble and Slatyer (1980), Enright et al. (2007), He et al. 2019, also persistence niche theory (Bond and Midgley 2001)

seed release, fire-stimulated germination of soil-stored seeds, water/light/nutrients high, disease low, Cowling and Lamont (1987), Causley et al. (2016), lack of seed storage in savanna grasslands (Lamont et al. 2017)

Shrubland vs forest (Odion et al. 2010), shrubland vs hummock grassland (Wright 2018), savanna vs forest (Bond and Parr 2010), vegetation models in the absence of fire (Bond et al. 2005)
Assess ways that the component species respond to a particular disturbance type to determine to what extent the dichotomy holds, including varying the properties of the disturbance, such as intensity and frequency

Any system with varying levels of patchiness (mosaics) from a range of causes (e.g., mosaics of soil, invasive species, micro-topography) within matched areas of equal total size can be used to test this hypothesis

Assess species composition before and after applying a particular disturbance type and examine the reasons for the match or mismatch

Determine the optimal conditions for stimulating germination and seedling recruitment - this requires simultaneous comparison of a number of disturbance or stress constraints, possibly varying in intensity, against a common control, ideally undertaken in the field

Impose widespread disturbance and gauge vegetation and species presence/ diversity change and to what extent they are self-perpetuating (Odion et al. 2010)

\section{Ecosystem functioning}

\section{The rate of disturbance (fire frequency) \\ controls the rate of carbon and nutrient cycling \\ Goldammer et al. (2009), Wittkuhn et al. (2017) \\ Archibald et al. (2018)}

12. Volatilization of carbon and mineral nutrients (due to fire) is a key contributor to their ecosystem cycling
Goldammer et al. (2009), Wang et al. (2016), Wittkuhn et al. (2017), Archibald et al. (2018), Butler et al. (2018)
Field trials are required where the disturbance type of interest varies in intensity and the effect on carbon or nutrient cycling is monitored. Where the ability to manipulate the system is limited, modelling will help to predict the outcomes

Volatilization is difficult to study directly. One approach is to determine base levels of carbon or nutrients and what remains after the disturbance and the difference is what has been lost in volatilization 
13. Specificity of plant-animal relations and animal-animal relations is relaxed in disturbed systems (due to frequent change in species presence and abundance)
Many animals that have major impacts on ecosystem functioning are omnivores or generalists, emus (seed dispersers), honeyeaters (pollinators), cockatoos (granivores), ants (seed buriers), insects generally (Koltz et al. 2018)
Present animals with a wide range of potential diet items, whose presence and abundance vary with the intensity of disturbance, and monitor what they select via direct observations or examination of droppings or stomach contents

Evolutionary processes

14. Fire-heat is a key agent for inducing genome Pettersson (1961), Pécrix et al. (2011), much duplication and polyploidization among flowering plants

15. Fire-(disturbance)-related traits are fire(disturbance)-adapted as they evolved after (or rarely coincidentally with) the onset of fire(disturbance)-proneness within their ancestral habitats

16. Fire (disturbance) promotes speciation via population turnover and dispersal effects but, more fundamentally, because fire itself is a polyploidization occurred either side of the fiery K-T event (Vanneste et al. 2014, He and Lamont 2018b)

source of mutagens

17. Abundance and impact of somatic mutations Lamont and Wiens (2003), Fowler et al. (2018), He depends on the intensity and length of exposure and Lamont (2018b)

of meristems to mutagenic agents, and

opportunities for their expression via bud

burst (i.e., postfire)
Confirmed for the Pinaceae, Proteaceae, Orchidaceae Haemodoraceae, Xanthorrhoeaceae, Restionaceae,

Fabaceae using trait-assignment techniques (Lamont and He 2017, Lamont et al. 2019b)

Plants (Wells 1969, He and Lamont (2018b), insects (Koltz et al. 2018)
Genome duplication and polyploidization are proposed as significant mechanisms in the diversification of plants but their cause over the long evolutionary time of life on Earth is unclear. Vanneste et al. (2014) attribute high levels around the K$\mathrm{T}$ boundary to "severe disturbance" events but give no details. The discovery of fire-heat induced genome duplication and polyploidization may be the key to diversification of flowering plants but other sources of disturbance need to be tested as well

Comprehensive dated phylogenies are required for clades whose adaptive traits to specific disturbances among its extant species are well established. Independent evidence for the presence of the relevant agent of disturbance at the time of the estimated time of origin of the trait is desirable. Validity of the results is enhanced when there is strong support from dated fossils for dating the phylogeny, estimating the evolutionary environment and providing direct evidence of the existence of the trait through time

Set up a field trial to test if the disturbance type of interest promotes population turnover and record pre- and post-disturbance genotypes. There is evidence that cold treatments can induce mutagenesis and other disturbance types could be assessed for their mutagenicity

The accumulation of mutagens is difficult to study. However, determining to what extent the disturbance type of interest promotes bud burst by resprouters is the expression part of mutagenesis that is easily studied and compared against controls 
18. Evolution of flammability and fire-adapted traits is the result of niche construction processes at all scales

19. Wildfire (widespread disturbance) causes rapid genetic/phenotypic adaptation among the impacted biota

20. Fluctuating levels of atmospheric oxygen and carbon dioxide over geological time scales have had a key role in controlling fireproneness (habitat flammability), evolution of fire-related traits and plant speciation rates, and pre-empted control by rainfall seasonality
Mutch (1970), Bond and Midgley (1995), Zedler (1995), Schwilk and Ackerly (2001), Schwilk (2003), He et al. (2011), He et al. (2012), Pausas et al. (2017), Staver and Schertzer (2018)

Genetically based melanism among grasshoppers (Tetrix subulata) is negatively correlated with time since fire (Forsman et al. 2011), insects (Koltz et al. 2018)

Oxygen levels control flammability (Belcher et al. 2010), major plant orders arose during the fiery

Cretaceous (He and Lamont 2018a), evolution of firerelated traits and speciation rates correlate with oxygen levels (He and Lamont 2018b, Lamont et al. 2019a), seasonal effects took over from oxygen level in the late Cenozoic (Lamont and He 2017). The importance for plants of the changes in atmospheric $\mathrm{O}_{2}$ through geological time (Bond and Scott 2010)
Assess if the increase of fire activities in otherwise relatively fire-free ecosystems leads to increased flammability and fire-adapted traits, thereby increasing fire activities through niche construction process and promoting an evolutionary feedback loop. As fire-adapted traits and flammability could be predicted from the fire regime the vegetation experiences, it may be feasible to use niche construction theory to make a general, formal predictions about organism traits and responses

Sudden and widespread disturbances are severe selective agents but are shortlived. To the extent that rapid adaptation is required (especially if the biota remains resident), genotype/phenotype fluctuations can be assessed by comparing them against disturbance events for their levels of synchronization.

This hypothesis gives causal explanations for fluctuating fire regimes over geological timespans and thence its effects on the associated biota. Unexplored is how these same atmospheric fluctuations may have affected the incidence of other disturbances and the consequent effects on evolutionary processes. Ther are geological records for the incidence of disturbances noted under (5) above and correlations can be undertaken. Models are available for the effect of the 'greenhouse effect' (high carbon dioxide) on the incidence of flooding,

hurricanes and the like, and meteorites on cloudiness, temperatures and the like. It is doubtful that varying oxygen levels affect other disturbance types. 
disturbance types most likely apply to particular firerelated theories and suggest suitable methodological approaches for testing them. As the opposite of fire heat, bouts of extreme cold can be expected to have a profound effect on population and community dynamics and evolutionary processes (Rabosky et al. 2018). Frost prunes back plants in a way equivalent to fire and it has been suggested is responsible for evolution of the subshrub geoxylic growth form in African grasslands (Finckh et al. 2016). Although it has since been shown to be historically implausible in this case (fire effects on such a growth form preceded frost-proneness, Lamont et al. 2017), frostresistance may evolve among young plants in frostprone populations (Prunier et al. 2012) while coldtolerant genes can be 'switched on' by low temperatures (Rensink et al. 2005).

As a further example, the reviewer, Marcelo Simon, points out that seasonal flooding of vegetation in river floodplains has parallels with fire disturbance: the incumbent plants are either flood tolerant or recolonize the plain after the water retreats (Parolin et al. 2003, Arias et al. 2018). This is equivalent to resprouters and nonsprouters (reestablish from seeds) in fireprone ecosysems, and their dynamics can be compared with theories 1,4 to 10 in Table 2 developed for fireprone floras.

Finally, we outline the steps that we have previously taken in seeking to understand the role of fire in plant evolution (Box 1). We offer this as a template that could be used for research programs on other disturbance types that may have an evolutionary impact. This approach requires comprehensive dated phylogenies for clades whose adaptive traits to specific disturbances among its extant species are well known. Independent evidence for the presence of the relevant agent of disturbance at the time of the estimated time of origin of the trait is desirable. Validity of the results is enhanced when there is strong support from dated fossils for giving a time dimension to the phylogeny, estimating the evolutionary environment and providing direct evidence of the existence of the trait through time (Lamont et al. 2019a).

\section{Conclusions}

Progress in ecology, biogeography and evolutionary biology is made through synthesising accumulated results into general patterns, identifying underlying mechanisms and testing consistency of predictions derived from hypotheses (Knapp et al. 2004). Most advances will be made when these procedures are undertaken on the three dimensions (major groups of constraints) that control the structure and dynamics of ecosystems (environmental factors, biotic interactions, and disturbances). Although it is the most prominent disturbance in nature, any explanatory role for fire is sometimes overlooked, misunderstood or dismissed (Pausas and Lamont 2018, Pausas and Bond 2019) or branded as an unnatural destructive force to be suppressed (Pyne 2016). Yet much is known about the key role of fire in ecosystem functioning and as a selective agent in trait evolution and speciation. Although none of the 100 'fundamental' questions (Sutherland et al. 2013) specifically mentions fire and its role in ecosystem and evolutionary processes, we show that fire-related research can address, or already has shed light on, 55 of them. Further, we identify 20 theories/models developed in fireprone systems that we believe need to be taken seriously by the rest of the ecological/evolutionary community in order to avoid "reinventing the wheel". We outline ways that these ideas and approaches can be tested in other systems for their applicability, especially in

Box 1. The steps involved in documenting the evolution of fire-adapted traits and firestimulated speciation that can be used as a template for pursuing evolutionary processes in other disturbance-prone systems.

1. The ecosystem becomes fireprone for the first time or the fire regime changes (Lamont and He 2017)

2. Fire causes population turnover and promotes emergence of novel genotypes and may itself be a source of mutagens that may cause changes in the genome of individuals in the affected population (He and Lamont 2018b)

3. Directional selection takes place, depending on genetic variation in the population and the type of mutations caused by fire, some individuals (phenotypes) respond negatively (local extinction or reduced fecundity) and others respond positively (local survival or increased fecundity)

4. The genetic structure of the population changes, and thus new trait types arise that increase fitness under the new fire regime (Simon et al. 2009, Maurin et al. 2014)

5. The new genotypes proliferate (stabilizing selection) and further speciation may now occur under the influence of other (secondary) agents of selection present in the new habitats now occupied (Lamont et al. 2019a)

6. The extent of speciation will depend on a) the range of fire regimes available to the ancestral species, as each regime type will induce a separate evolutionary pathway, b) the range of other selective agents present within a given fire regime, c) the genetic heterogeneity of the component clades, and hence trait options available to respond positively to the new fire regime, d) the mutagenic properties of the fires that occur, e) (meta)population dynamics of the affected species, and f) the passage of geological time available (Dolan et al. 2008) 
response to sources of disturbance and severe stresses other than fire.

The Anthropocene is an era with unprecedented biotic mixing, where ecosystems are altered and novel plant-trait combinations are emerging. Flammability is not only prominent in fireprone ecosystems, but is also becoming relevant in previously relatively fire-free regions with climatic change and plant invasion; and the impact of wildfire in many regions is escalating (Moritz et al. 2014). Note the wide occurrences of severe fires in Eastern Australia and California in 2019-20 that show how this dimension can have a profound effect on ecosystems not previously thought to be highly fireprone (Clarke et al. 2020). We exhort field biologists and theoreticians alike to include fire and other disturbances in their thinking about possible critical environmental constraints operating on the biota and ecosystems that they study. Adding the third dimension to research endeavours may require a change in the objectives of some projects but it will greatly enrich our understanding of how nature works at the global scale.

\section{Acknowledgements}

BBL and TH's research on fire ecology and firerelated evolution has received support from the Australian Research Council. We thank Juli Pausas for his insights on the contributions of fire-related constraints to biological phenomena and fire-related research to ecology and evolutionary biology. Thanks to Stephen Pyne and Marcelo Simon and other colleagues for their valuable comments on previous drafts of this paper. All data underlying the findings are fully available without restriction. All datasets used to support this review are available in the Appendix and reference lists.

\section{Referees}

Stephen Pyne - Stephen.Pyne@asu.edu Arizona State University

Marcelo Simon - Marcelo.Simon@embrapa.br Empresa Brasileira de Pesquisa Agropecuaria

\section{References}

Archibald, S., Lehmann, C., Belcher, C., Bond, W., Bradstock, R., Daniau, et al. 2018. Biological and geophysical feedbacks with fire in the Earth system. Environmental Research Letters 13(3). CrossRef

Archibald, S., Lehmann, C.E.R., Gomez-Dans, J.L., and R.A. Bradstock. 2013. Defining pyromes and global syndromes of fire regimes. Proceedings of National Academy of Sciences 110: 6442-6447. $\underline{\text { CrossRef }}$

Arias, M.E., Wittmann, F., Parolin, P., MurrayHudson, M., and T.A. Cochrane. 2018. Interactions between flooding and upland disturbance drives species diversity in large river floodplains. Hydrobiologia 814: 5-17. CrossRef

Belcher, C.M., Yearsley, J.M., Hadden, R.M., McElwain, J.C., and G. Rein. 2010. Baseline intrinsic flammability of Earth's ecosystems estimated from paleoatmospheric oxygen over the past 350 million years. Proceedings of the National Academy of Sciences 107: 2244822453. CrossRef

Bellingham, P. J., and A.D. Sparrow. 2000. Resprouting as a life history strategy in woody plant communities. Oikos 89: 409-416. CrossRef

Bond, W.J., and J.J. Midgley. 1995. Kill thy neighbour, an individualistic argument for the evolution of flammability. Oikos 73: 79-85. CrossRef

Bond, W.J., and J.J. Midgley. 2001. Ecology of sprouting in woody plants, the persistence niche. Trends in Ecology and Evolution 16: 45-51. CrossRef

Bond, W.J., and C.L. Parr. 2010. Beyond the forest edge: Ecology, diversity and conservation of the grassy biomes. Biological Conservation 143: 2395-2404. CrossRef

Bond, W.J., and A.C. Scott. 2010. Fire and the spread of flowering plants in the Cretaceous. New Phytologist 188: 1137-1150. CrossRef

Bond, W.J., Woodward, F.I., and G.F. Midgley. 2005. The global distribution of ecosystems in a world without fire. New Phytologist 165: 525538. CrossRef

Bowman, D.M.J.S., Balch, J.K., Artaxo, P., Bond, W.J., Carlson, J.M., Cochrane, et al. 2009. Fire in the Earth system. Science 324: 481-484. CrossRef

Brits, G.J. 1987. Germination depth vs. temperature requirements in naturally dispersed seeds of Leucospermum cordifolium and L. cuneiforme (Proteaceae). South African Journal of Botany 53: 119-124. CrossRef

Brown, S.A.E., Scott, A.C., Glasspool, I.J., and M.E. Collinson. 2012. Cretaceous wild fires and their impact on the Earth system. Cretaceous Research 36: 162-190. CrossRef

Butler, O.M., Elser, J.J., Lewis, T., Mackey, B., and C. Chen. 2018. The phosphorus-rich signature of fire in the soil-plant system, a global metaanalysis. Ecology Letters 21: 335-344. CrossRef

Causley, C.L., Fowler, W.M., Lamont, B.B., and T. He. 2016. Fitness benefits of serotiny in fire- and drought-prone environments. Plant Ecology 217: 773-779. CrossRef

Clarke, H., Penman, T., Boer, M., Cary, G.J., Fontaine, J. B., Price, O. et al. 2020. The proximal drivers of large fires: a pyrogeographic study. Frontiers in Earth Science: 8: 90. CrossRef

Cowling, R.M., and B.B. Lamont. 1987. Post-fire recruitment of four co-occurring Banksia species. Journal of Applied Ecology 24: 645-658. CrossRef

Crisp, M.D., Burrows, G.E., Cook, L.G., Thornhill, A.H., and D.M.J.S. Bowman. 2011. Flammable 
biomes dominated by eucalypts originated at the Cretaceous-Palaeogene boundary. Nature Communications 2: 193. CrossRef

Davies, H.F., McCarthy, M.A., Rioloi, W., Puruntatameri, J., Roberts, W., Kerinaiua, C., et al. 2018. An experimental test of whether pyrodiversity promotes mammal diversity in a northern Australian savanna. Journal of Applied Ecology 55: 2124-2134. CrossRef

Dolan, R.W., Quintana-Ascencio, P.F., and E.S. Menges. 2008. Genetic change following fire in populations of a seed-banking perennial plant. Oecologia 158: 355-360. CrossRef

Enright, N.J., and B.B. Lamont. 1989. Seed banks, fire season, safe sites and seedling recruitment in five co-occurring Banksia species. Journal of Ecology 77: 1111-1122. CrossRef

Enright, N.J., Mosner, E., Miller, B.P., Johnson, N., and B.B. Lamont. 2007. Soil versus canopy seed storage and plant species coexistence in speciesrich shrublands of southwestern Australia. Ecology 88: 2292-2304. CrossRef

Finckh, M., Revermann, R., and M.P. Aidar. 2016. Climate refugees going underground - a response to Maurin et al (2014). New Phytologist 209: 904-909. CrossRef

Forsman, A., Karlsson, M. Wennersten, L. Johansson, J., and E. Karpestam. 2011. Rapid evolution of fire melanism in replicated populations of pygmy grasshoppers. Evolution 65: 2530-2540. CrossRef

Fowler, W., Deng, X., Lamont, B.B., and T. He. 2018. Resprouters, assisted by somatic mutations, are as genetically diverse as nonsprouters in the world's fireprone ecosystems. Acta Oecologica 92: 1-8. CrossRef

Glasspool, I.J., Edwards, D., and L. Axe. 2004. Charcoal in the Silurian as evidence for the earliest wildfire. Geology 32: 381-383.CrossRef

Goldammer, J.G., Statheropoulos, M., and M. Andreae. 2009. Impacts of vegetation fire emissions on the environment, human health, and security: a global perspective. Pages 3-36 In: Bytnerowicz, A., Arbaugh, M., Riebau, A., Andersen, C., Editors. Wildland Fires and Air Pollution. Developments in Environmental Science, volume 8. Elsevier, Amsterdam. CrossRef

Grubb, P., and J. Whittaker. 2014. 100 Influential papers published in 100 years of the British Ecological Society journals. British Ecological Society, London.

He, T., and B.B. Lamont. 2018a. Baptism by fire, the pivotal role of ancient conflagrations in evolution of the Earth's flora. National Science Review 5: 237-254. CrossRef

He, T., and B.B. Lamont. 2018b. Fire as a potent mutagenic agent among plants. Critical Reviews in Plant Sciences 37: 1-14. CrossRef

He, T., Lamont, B.B., and K.S. Downes. 2011. Banksia born to burn. New Phytologist 191: 184 196. $\underline{\text { CrossRef }}$
He, T., Lamont, B.B. and J.G. Pausas. 2019. Fire as a key driver of the Earth's biodiversity. Biological Reviews 94(6): 1983-2010. CrossRef

He, T., Pausas, J.G., Belcher, C.M., Schwilk, D.W., and B.B. Lamont. 2012. Fire-adapted traits of Pinus arose in the fiery Cretaceous. New Phytologist 194: 751-759. CrossRef

Keeley, J.E., Pausas, J.G., Rundel, P.W., Bond, W.J., and R.A. Bradstock. 2011. Fire as an evolutionary pressure shaping plant traits. Trends in Plant Science 16: 406-411. CrossRef

Kelly, A.E., and M.L. Goulden. 2008. Rapid shifts in plant distribution with recent climate change. Proceedings of the National Academy of Sciences 105: 11823-11826. CrossRef

Knapp, A.K., Smith, M.D., Collins, S.L., Zambatis, N., Peel, K., Emery, S., et al. 2004. Generality in ecology: Testing North American grassland rules in South African savannas. Frontiers in Ecology and the Environment 2: 483-491. CrossRef

Koltz, A.M., Burkle, L.A., Pressler, Y., Dell, J.E., Vidal, M.C., Richards, L.A., et al. 2018. Global change and the importance of fire for the ecology and evolution of insects. Current Opinion in Insect Science 29: 110-116. CrossRef

Lamont, B.B., and K.S. Downes. 2011. Firestimulated flowering among resprouters and geophytes in Australia and South Africa. Plant Ecology 212: 2111-2125. CrossRef

Lamont, B.B. and T. He. 2017. Fireproneness as a prerequisite for the evolution of fire-adapted traits. Trends in Plant Science 22: 278-288. CrossRef

Lamont, B.B., He, T., and J.G. Pausas. 2017. African geoxyles evolved in response to fire, frost came later. Evolutionary Ecology 31: 306-317. CrossRef

Lamont, B.B., and D. Wiens. 2003. Are seed set and speciation always low among species that resprout after fire, and why? Evolutionary Ecology 17: 277-292. CrossRef

Lamont, B.B., He, T., and Z. Yan. 2019a. Evolutionary history of fire-stimulated resprouting, flowering, seed release and germination. Biological Reviews 94: 903-928. CrossRef

Lamont, B.B., He, T., and Z. Yan. 2019b. Fire as a pre-emptive evolutionary trigger among seed plants. Perspectives in Plant Ecology, Evolution and Systematics 36: 13-23. CrossRef

Lamont, B.B., Witkowski, E.T.F., and N.J. Enright. 1993. Post-fire litter microsites: safe for seeds, unsafe for seedlings. Ecology 74: 501-512. CrossRef

Lavorel, S., and E. Garnier. 2002. Predicting changes in community composition and ecosystem functioning from plant traits: revisiting the Holy Grail. Functional Ecology 16: 545-556. CrossRef

Martin, R.E. and D.B. Sapsis. 1992. Fires as agents of biodiversity: pyrodiversity promotes biodiversity. Proceedings of the Symposium on Biodiversity in Northwestern California. 
Wildland Resources Centre, University of California, Berkeley.

Maurin, O., Davies, T.J., Burrows, J.E., Daru, B.H., Yessoufou, K., Muasya, A.M. et al. 2014. Savanna fire and the origins of the 'underground forests' of Africa. New Phytologist 204: 201-214. CrossRef

Milberg, P., and B.B. Lamont. 1995. Fire enhances weed invasion of roadside vegetation in southwestern Australia. Biological Conservation 2: 45-49. CrossRef

Moreira, B., and J.G. Pausas. 2012. Tanned or burned: the role of fire in shaping physical seed dormancy. PLoS ONE 7: e51523. CrossRef

Moritz, M.A., Batllori, E., Bradstock, R.A., Gill, A.M., Handmer, J., Hessburg, P.F., et al. 2014. Learning to coexist with wildfire. Nature 515: 58-66. CrossRef

Mutch, R.W. 1970. Wildland fires and ecosystems A hypothesis. Ecology 51: 1046-1051. CrossRef

Noble, I.R., and R.O. Slatyer. 1980. The use of vital attributes to predict successional changes in plant communities subject to recurrent disturbances. Vegetatio 43: 5-21. CrossRef

Odion, D.C., Moritz, M.A. and D.A. Dellasala. 2010. Alternative community states maintained by fire in the Klamath Mountains, USA. Journal of Ecology 98: 96-105. CrossRef

Osborne, C.P. 2008. Atmosphere, ecology and evolution: what drove the Miocene expansion of C4 grasslands? Journal of Ecology 96: 35-45. CrossRef

Parolin, P., Ferreira, L.V., and W.J. Junk. 2003. Germination characteristics and establishment of trees from central Amazonian flood plains. Tropical Ecology 44: 155-168.

Pausas, J.G., and J.E. Keeley. 2009. A burning story: the role of fire in the history of life. BioScience 59: 593-601. CrossRef

Pausas, J.G., and J.E. Keeley. 2014. Evolutionary ecology of resprouting and seeding in fire-prone ecosystems. New Phytologist 204: 55-65. CrossRef

Pausas, J.G., Keeley, J.E. and D.W. Schwilk. 2017. Flammability as an ecological and evolutionary driver. Journal of Ecology 105(2): 289-297. CrossRef

Pausas, J. G., and B.B. Lamont. 2018. Ecology and biogeography in 3D, the case of the Australian Proteaceae. Journal of Biogeography 45: 14691477. CrossRef

Pausas, J.G., and E. Ribeiro. 2017. Fire and plant diversity at the global scale. Global Ecology and Biogeography 26: 889-97. CrossRef

Pausas, J.G. and W.J. Bond. 2019. Humboldt and the reinvention of nature. Journal of Ecology 107: 1031-1037. CrossRef

Pécrix, Y., Rallo, G., Folzer, H., Cigna, M., Gudin, S., and M. Le Bris. 2011. Polyploidization mechanisms: temperature environment can induce diploid gamete formation in Rosa sp. Journal of Experimental Botany 62: 3587-3597. CrossRef
Pettersson, B. 1961. Mutagenic effect of radiant heat shocks on phanerogamous plants. Nature 191: 1167-1169. CrossRef

Prunier, R., Holsinger, K. E., and J.E. Carlson. 2012. The effect of historical legacy on adaptation: do closely related species respond to the environment in the same way? Journal of Evolutionary Biology 25: 1636-1649. CrossRef

Pyne, S.J. 2016. Fire in the mind, changing understandings of fire in western civilization. Philosophical Transactions of Royal Society B 371: 20150166. CrossRef

Rabosky, D.L., Chang, J., Title, P.O., Cowman, P. F., Sallan, L., Friedman, M., et al. 2018. An inverse latitudinal gradient in speciation rate for marine fishes. Nature 559: 392-395. CrossRef

Randerson, J.T., Liu, H., Flanner, M.G., Chambers, S.D., Jin, Y., Hess, P.G., et al. 2006. The impact of boreal forest fire on climate warming. Science 314: 1130-1132. CrossRef

Rensink, W.A., Iobst, S., Hart, A., Stegalkina, S., Liu, J., and C.R. Buell. 2005. Gene expression profiling of potato responses to cold, heat, and salt stress. Functional and Integrative Genomics 5: 201-207. CrossRef

Santana, V.M., Baeza, M.J., and M.C. Blanes. 2013. Clarifying the role of fire heat and daily temperature fluctuations as germination cues for Mediterranean Basin obligate seeders. Annals of Botany 111: 127-134. CrossRef

Schütz, S., Weissbecker, B., Hummel, H.E., Apel, K. H., Schmitz, H. and H. Bleckmann. 1999. Insect antennae as a smoke detector. Nature 398: 298299. CrossRef

Schwilk, D.W. 2003. Flammability is a niche construction trait: canopy architecture affects fire intensity. American Naturalist 162: 725-733. CrossRef

Schwilk, D.W., and D.D. Ackerly. 2001. Flammability and serotiny as strategies: correlated evolution in pines. Oikos 94: 326-336. CrossRef

Schwilk, D.W., and J.E. Keeley. 2012. A plant distribution shift: temperature, drought or past disturbance? PLoS ONE 7: e31173. CrossRef

Simon, M.F., Grether, R., de Queiroz, L.P., Skema, C., Pennington, R.T., and C.E. Hughes. 2009. Recent assembly of the Cerrado, a neotropical plant diversity hotspot, by in situ evolution of adaptations to fire. Proceedings of the National Academy of Sciences 106: 20359-20364. CrossRef

Sutherland, W.J., Freckleton, R.P., Godfray, H.C.J., Beissinger, S.R., Benton, T., Cameron, D.D., et al. 2013. Identification of 100 fundamental ecological questions. Journal of Ecology 101: 58-67. CrossRef

Vanneste, K., Baele, G., Maere, S., and Y. van de Peer. 2014. Analysis of 41 plant genomes supports a wave of successful genome duplications in association with the CretaceousPaleogene boundary. Genome Research 24: 1334-1347. CrossRef 
Wang, R., Balkanski, Y., Boucher, O., Ciais, P., Peñuelas, J., and S. Tao. 2015. Significant contribution of combustion-related emissions to the atmospheric phosphorus budget. Nature Geoscience 8: 48. CrossRef

Wells, P.V. 1969. The relation between mode of reproduction and extent of speciation in woody genera of the California chaparral. Evolution 23: 264-267. CrossRef

Wittkuhn, R.S., Lamont, B.B., and T. He. 2017. Combustion temperatures and nutrient transfers when grasstrees burn. Forest Ecology and Management 399: 179-187. CrossRef

Zedler, P.H. 1995. Are some plants born to burn? Trends in Ecology and Evolution 10: 393-395. CrossRef

\section{Response to Referee}

It is encouraging to have support for our commentary from such an authority on the place of fire on Earth as Stephen Pyne (e.g., Pyne 2019). Others might just see our exhortations as sour grapes over perceived lack of interest in our research endeavours. On the contrary, Pyne (2020) considers that we do not go far enough. We argue for fire, and disturbance ecology in general, as worthy of equal status with the traditional controlling influences, climate, topography and soils (abiotic factors) and to a lesser extent, biotic interactions (herbivory, pollination and the like) in research. Pyne sees fire as even more fundamental in understanding nature than these. This is because fire is inextricably part of nature. In support of this view, we have argued elsewhere (Lamont, He and Yan 2019) that fire pre-empts these other influences historically in many instances; that is, they only have a secondary, 'fine-tuning' role that comes into operation after fire has shaped the basic adaptations of plants in particular.

Pyne's comments are so insightful that for us to sprinkle them through the manuscript would have been an act of plagiarism. He alone must take credit for them. It is surely a classic comment from him that fire studies got relegated to forestry who did not want it and then this land management authority did all it could to suppress fire so that they did not have to deal with it - recent events in California and Australia show that fire has certainly come back to bite the hand that fed it (so well)! The dilemma is that, while (wild)fire is fundamental to maintaining nature's processes (He et al. 2019), it is incompatible with the presence of humans in the landscape. Yet humans now control the incidence of fire and we accept the criticism that we have not addressed the implications of this adequately in arguing for a greater recognition of fire-related biology in our research endeavours.

Creative management must find ways to let fireprone ecosystems operate in such a way as to maintain biodiversity (ad hoc fire suppression is not effective land management) while keeping humanoccupied areas fire-free. We believe that the firerelated traits possessed by biota provide the necessary clues as to their optimal conservation management. It is a major, and now perhaps urgent, task for researchers to find out what these properties are. This knowledge needs to be passed onto land managers whose objectives must include biodiversity conservation as well as protection of life and property.

Pyne, S. 2019. Fire: A Brief History. $2^{\text {nd }}$ ed. University of Washington Press.

Pyne, S. 2020. A uniquely fire creature, a uniquely fire planet. Ideas in Ecology and Evolution 13: 59-60. CrossRef

Lamont, B.B., He, T., and Z. Yan. 2019. Fire as a pre-emptive evolutionary trigger among seed plants. Perspectives in Plant Ecology, Evolution and Systematics 36: 13-23. CrossRef

He, T., Lamont, B.B. and J.G. Pausas. 2019. Fire as a key driver of the Earth's biodiversity. Biological Reviews 94: 983-2010. CrossRef 


\section{Appendices}

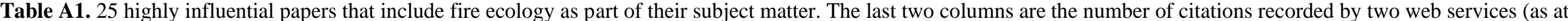
10 July 2019) with the listing order determined by the first. The 11 papers whose main theme is fire effects are indicated by $*$.

\begin{tabular}{|c|c|c|c|c|c|c|c|}
\hline Title & Authors & Year & Journal & Vol & Pages & $\begin{array}{l}\text { Web of } \\
\text { Science }\end{array}$ & $\begin{array}{l}\text { Google } \\
\text { Scholar }\end{array}$ \\
\hline $\begin{array}{l}\text { Biotic invasions, causes, epidemiology, global } \\
\text { consequences, and control }\end{array}$ & $\begin{array}{l}\text { Mack, R.N., Simberloff, D. } \\
\text { Lonsdale, W.M., et al. }\end{array}$ & 2000 & Ecological Applications & 10 & $689-710$ & 3508 & 6283 \\
\hline $\begin{array}{l}\text { Warming and earlier spring increase western US forest } \\
\text { wildfire activity* }\end{array}$ & $\begin{array}{l}\text { Westerling, A.L., Hidalgo, H.G., } \\
\text { Cayan, D.R., et al. }\end{array}$ & 2006 & Science & 313 & $940-943$ & 2430 & 4009 \\
\hline $\begin{array}{l}\text { Northern peatlands - role in the carbon-cycle and } \\
\text { probable responses to climatic warming }\end{array}$ & Gorham, E. & 1991 & Ecological Applications & 1 & $182-195$ & 2161 & 3503 \\
\hline $\begin{array}{l}\text { Emission of trace gases and aerosols from biomass } \\
\text { burning* }\end{array}$ & Andreae, M.O., Merlet, P. & 2001 & $\begin{array}{l}\text { Global Biogeochemical } \\
\text { Cycles }\end{array}$ & 15 & $955-966$ & 2071 & 3308 \\
\hline $\begin{array}{l}\text { Nitrogen limitation on land and in the sea - how can it } \\
\text { occur? }\end{array}$ & Vitousek, P.M., Howarth, R.W. & 1991 & Biogeochemistry & 13 & $87-115$ & 2040 & 3196 \\
\hline $\begin{array}{l}\text { Biological invasions by exotic grasses, the grass fire } \\
\text { cycle, and global change }\end{array}$ & Dantonio, C.M., Vitousek, P.M. & 1992 & $\begin{array}{l}\text { Annual Review of Ecology } \\
\text { and Systematics }\end{array}$ & 23 & $63-87$ & 1855 & 3339 \\
\hline $\begin{array}{l}\text { Evaluation of ecosystem dynamics, plant geography and } \\
\text { terrestrial carbon cycling in the LPJ dynamic global } \\
\text { vegetation model }\end{array}$ & $\begin{array}{l}\text { Sitch, S., Smith, B., Prentice, } \\
\text { I.C., et al. }\end{array}$ & 2003 & Global Change Biology & 9 & $161-185$ & 1708 & 2642 \\
\hline Tree-grass interactions in savannas & Scholes, R.J., Archer, S.R. & 1997 & $\begin{array}{l}\text { Annual Review of Ecology } \\
\text { and Systematics }\end{array}$ & 28 & $517-544$ & 1427 & 2285 \\
\hline $\begin{array}{l}\text { Disturbance, diversity, and invasion - implications for } \\
\text { conservation }\end{array}$ & Hobbs, R.J., Huenneke, L.F. & 1992 & Conservation Biology & 6 & $324-337$ & 1295 & 2590 \\
\hline Predicting changes in community composition and & Lavorel, S., Garnier, E. & 2002 & Functional Ecology & 16 & $545-556$ & 1430 & 2223 \\
\hline
\end{tabular}

ecosystem functioning from plant traits, revisiting the

Holy Grail 
Global fire emissions and the contribution of

deforestation, savanna, forest, agricultural, and peat

fires (1997-2009)*

Fire in the Earth System*

Effects of fire on properties of forest soils, a review

Climate change and forest disturbances

The global distribution of ecosystems in a world without fire*

Fire as a global 'herbivore', the ecology and evolution of Bond, W.J., Keeley, J.E. flammable ecosystems*

Fire effects on belowground sustainability, a review and synthesis

Ecology of sprouting in woody plants, the persistence niche

Effects of invasive alien plants on fire regimes*

Fire, resprouting and variability, a recipe for grass-tree coexistence in savanna*

Plant diversity in Mediterranean-climate regions

What limits trees in C-4 grasslands and savannas?* van der Werf, G.R., Randerson,

2010

J.T., Giglio, L., et al.

Bowman, D.M.J.S., Balch, J.K., 2009 Artaxo, P., et al.

Certini, G.

Dale, V.H., Joyce, L.A., McNulty, S., et al.

Bond, W.J., Woodward, F.I. Midgley, G.F

Neary, D.G., Klopatek, C.C DeBano, L.F., et al.

Bond, W.J., Midgley, J.J.

Brooks, M.L., D'antonio, C.M., Richardson, D.M., et al.

Higgins S.I., Bond W.J.,

Trollope, W.S.W.

Cowling, R.M., Rundel, P.W.,

Lamont, B.B., et al.

Bond, W.J.
2005

Atmospheric Chemistry

Science

2005

2001

Oecologia

BioScience

New Phytologist

Trends In Ecology \&

Evolution

Forest Ecology and

Management

Trends In Ecology \&

Evolution

BioScience

2000

1996

2008

Ecology

Trends In Ecology \&

Evolution and Physics

11707-

11735

Annual Review of Ecology

Evolution and Systematics
324

$481-484$

1113

1704

179

329 
Recent assembly of the Cerrado, a neotropical plant diversity hotspot, by in situ evolution of adaptations to

fire*

Effects of fire and herbivory on the stability of savanna ecosystems* Vijver, C.A.D.M., Kumar, L., et

A burning story, the role of fire in the history of life* van Langevelde, F., van de al.

Simon, M.F.; Grether, R., de Queiroz, L.P., et al.

Pausas, J.G., Keeley, J.E
States of America

Ecology 


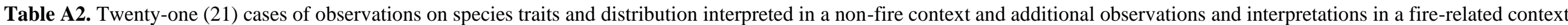

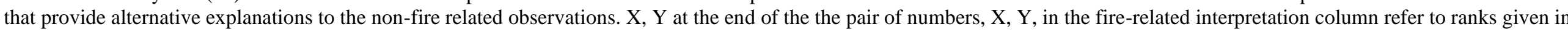
Table 1 for relative importance of fire-related interpretation $(\mathrm{X})$ and relative time of origin of fire-related constraint $(\mathrm{Y})$

\begin{tabular}{|c|c|c|c|c|c|}
\hline Observations & $\begin{array}{l}\text { Interpretation not } \\
\text { taking fireproneness } \\
\text { into account }\end{array}$ & References & Fire-related observations & Fire-related interpretation & References \\
\hline \multicolumn{6}{|l|}{ Soil-stored seeds } \\
\hline $\begin{array}{l}\text { 1. Seeds dispersed onto } \\
\text { soil in South American } \\
\text { savanna lack or have } \\
\text { weak dormancy }\end{array}$ & $\begin{array}{l}\text { Adaptation to a reliable } \\
\text { wet season suitable for } \\
\text { recruitment in any year }\end{array}$ & $\begin{array}{l}\text { Dayrell et } \\
\text { al. } 2016\end{array}$ & $\begin{array}{l}\text { Vegetation burnt every } 1-3 \text { years at start of wet season, } \\
\text { seeds survive fire but germination is fire-independent }\end{array}$ & $\begin{array}{l}\text { Seeds heat tolerant but dormancy } \\
\text { redundant as conditions may be suitable } \\
\text { for germination within the year so that } \\
\text { a fire cue is not required and storage } \\
\text { could come at a 'cost'. } 4,1\end{array}$ & Lamont et al. 2017 \\
\hline $\begin{array}{l}\text { 2. Aril-(elaiosome)- } \\
\text { bearing seeds are carried } \\
\text { by ants some distance } \\
\text { from their source and } \\
\text { into their nests from } \\
\text { which they may } \\
\text { germinate; this includes } \\
\text { crypsis from granivores }\end{array}$ & $\begin{array}{l}\text { Elaiosomes are an } \\
\text { adaptation for increasing } \\
\text { dispersal to 'safe sites' } \\
\text { among seeds that are } \\
\text { otherwise passively } \\
\text { dispersed }\end{array}$ & $\begin{array}{l}\text { Ness et al. } \\
2004, \\
\text { Christian } \\
\text { and Stanton } \\
2004\end{array}$ & $\begin{array}{l}\text { Elaiosome-bearing species are confined to fireprone } \\
\text { ecosystems; seeds are carried by ants to depths that insulate } \\
\text { them from the full heat of fire but still enable them to } \\
\text { receive a heat pulse that breaks dormancy and promotes } \\
\text { germination; the distances seeds are carried by ants is on } \\
\text { average only a few metres; unless the aril is removed, seeds } \\
\text { are still vulnerable to granivory by rodents }\end{array}$ & $\begin{array}{l}\text { The distance aril-bearing seeds are } \\
\text { carried by ants is too short and crypsis } \\
\text { too unreliable to be of adaptive } \\
\text { significance; elaiosomes ensure that } \\
\text { ants bury the seeds to variable depths } \\
\text { which can receive moderate heat pulses } \\
\text { that break dormancy as a 'bet-hedging' } \\
\text { strategy. } 3,2\end{array}$ & $\begin{array}{l}\text { Gómez and } \\
\text { Espadaler } 1998, \\
\text { Christian and } \\
\text { Stanton 2004, Kwit } \\
\text { et al. 2012, } \\
\text { Beaumont et al. } \\
2018\end{array}$ \\
\hline $\begin{array}{l}\text { 3. Hard (impermeable) } \\
\text { seeds worldwide lack } \\
\text { aroma, occur in } \\
\text { seasonally dry climates }\end{array}$ & $\begin{array}{l}\text { Hard seeds not } \\
\text { detectable by smell- } \\
\text { sensitive granivores } \\
\text { (cryptic); can better }\end{array}$ & $\begin{array}{l}\text { Paulsen et } \\
\text { al. 2013, } \\
\text { Wyse and } \\
\text { Dickie }\end{array}$ & $\begin{array}{l}\text { Hard seeds survive in the long absence of fire but fire is } \\
\text { required to break dormancy and most seedlings recruit } \\
\text { immediately postfire; regions with strongly seasonal } \\
\text { climates are also the most fireprone; seasonality in itself }\end{array}$ & $\begin{array}{l}\text { Hard seeds increase longevity that } \\
\text { exceeds intervals commensurate with } \\
\text { fire frequency; fire both signals the } \\
\text { onset of optimal conditions for }\end{array}$ & $\begin{array}{l}\text { Calviño-Cancela et } \\
\text { al. 2008, Lamont et } \\
\text { al. 2019a }\end{array}$ \\
\hline
\end{tabular}

andor survive digestion survive strongly seasonal 2018

does not break dormancy or else seeds would germinate

climates; increase fitness

every year; seeds may survive digestion but they are still

by surviving digestion

not primed to germinate-fire heat is required

recruitment and is the mechanism for

breaking dormancy. 4,1 
4. High summer temperatures in vegetation gaps produce significant dormancy breakage and germination of soilstored seeds

Germination of soilstored seeds is cued by high summer

temperatures (exposure to strong light) that signal the presence of vegetation gaps

5. Soil-stored seeds become permeable with time or when passing through digestive tract of animals

Decay processes, soil abrasion, digestion of hard seeds
Santana et Fire induces much higher levels of germination than al. 2013,

Ooi et al.

2014

Fire in summer-type temperatures, larger vegetation gaps, optimal conditions for recruitment and much higher levels of fecundity than interfire recruits. Interfire recruits will be younger when experiencing the next fire so producing fewer, if any, seeds

Soriano et Most seeds do not become permeable simply with the passage of time when soil-stored though their threshold abrasive agents and digestion ineffective at breaking dormancy; only heat (usually from fire) effective in breaking dormancy
Fitness at the individual and species levels is best promoted by fires that occur at fitful intervals as germination, 1998, Jaganathan et survival and fecundity are maximized postfire compared with interfire recruits. 4,3

al. 2017, Causley et al. 2016, Lamont et al. 2019a

Soil and digestion processes are ineffective at priming hard seeds for germination and heat is still required to break dormancy. 5,1

al. 2008, Zalamea

\section{et al. 2015,}

Liyanage and Ooi

2017

Plant-stored seeds

\begin{tabular}{|c|c|c|c|c|c|}
\hline $\begin{array}{l}\text { 6. On-plant seed storage } \\
\text { (serotiny) common } \\
\text { among pine trees in the } \\
\text { Mediterranean-type } \\
\text { climate of California }\end{array}$ & $\begin{array}{l}\text { Serotiny (closed cones) } \\
\text { is associated with } \\
\text { summer-dry, winter-wet } \\
\text { climates (no mention of } \\
\text { fire in the entire review) }\end{array}$ & $\begin{array}{l}\text { Raven and } \\
\text { Axelrod } \\
1978\end{array}$ & $\begin{array}{l}\text { Serotiny associated with woody cones/fruits is restricted to } \\
\text { fireprone floras; seed release is initiated by fire heat; most } \\
\text { recruitment occurs after fire }\end{array}$ & $\begin{array}{l}\text { Seeds held in fire-tolerant structures } \\
\text { that release their seeds in response to } \\
\text { fire heat that signals the onset of } \\
\text { optimal conditions for seedling } \\
\text { recruitment. } 5,1\end{array}$ & $\begin{array}{l}\text { Lamont and Enright } \\
2000\end{array}$ \\
\hline $\begin{array}{l}\text { 7. Woody fruits/cones } \\
\text { are rarely penetrated by } \\
\text { granivores }\end{array}$ & $\begin{array}{l}\text { Woody fruits/cones } \\
\text { serve to deter granivores } \\
\text { from reaching the } \\
\text { nutritious seeds }\end{array}$ & $\begin{array}{l}\text { Groom and } \\
\text { Lamont } \\
1997, \\
\text { Lamont et } \\
\text { al. } 2016\end{array}$ & $\begin{array}{l}\text { Woody fruits/cones protect seeds from the elements until } \\
\text { conditions are suitable for seedling recruitment as after fire; } \\
\text { woody fruits insulate seeds from full heat of fire; high } \\
\text { temperatures cause the rupture of woody fruits and release } \\
\text { of their seeds onto an optimal seedbed }\end{array}$ & $\begin{array}{l}\text { Woody fruits/cones are fire-related } \\
\text { adaptations that protect the seeds from } \\
\text { decay, granivores and fire heat during } \\
\text { storage, and that respond to fire heat by } \\
\text { dehiscing (pyriscence) and releasing } \\
\text { their seeds under optimal conditions for } \\
\text { seedling recruitment. } 4,1\end{array}$ & $\begin{array}{l}\text { Bradstock et al. } \\
\text { 1994, Lamont and } \\
\text { Enright } 2000\end{array}$ \\
\hline
\end{tabular}

Growth form

\section{South African} subshrub geoxyles (short woody resprouters) occur in frost-prone uplands
Low stature is a response Finckh et al. The subshrub geoxyle habit is associated with fireprone to pruning by frost and 2016 the woody underground structures enable them to resprout and recover habitats whether frost-prone or not and fire adaptations

(e.g. lignotuber) can be traced to fireprone, preMiocene times via ancestral trait assignment
Maurin et al. 2014,

The geoxyle habit evolved under Lamont et al. 2017 fireprone conditions that long prec the onset of recu 
9. Savanna grasses possess the highly efficient $\mathrm{C} 4$

photosynthetic pathway when $\mathrm{CO}_{2}$ is limiting growth

10.Resprouters among Restionaceae relatively more abundant in Australia than South

Africa
Grasses with the $\mathrm{C} 4$ pathway has given them 2010 an adaptive advantage

over $\mathrm{C} 3$ grasses

The mountainous

landscape (greater altitudinal variation) of South Africa promotes

diversification of nonsprouters 2014
Taylor et al. C4 grasses dominate highly fireprone grasslands; C4 grasses survive fire much better than $\mathrm{C} 3$ grasses because they are fire-tolerant through possessing soil-buried buds (rhizomes)

Litsios et al. Resprouters are associated with a greater range of fire frequencies than nonsprouters that require specific fire regimes; most Restionaceae require smoke to break seed dormancy (ancestral condition); rhizomatous habit gives fire protection and is ancestral; SW Australia has a longer and more intense fire history than S. Africa
C4 grasses have a competitive edge

to survive fire. 4,2 ausas and Paula 2019

Restionaceae probably arose in highly fireprone Australia where the

López-Villalta 2014, He et al rhizomatous habit gives fire protection 2016, Lamont et al. and smoke promotes germination; nonsprouting is a later development associated with more reliable, intermediately frequent fires more likely in S. Africa. 4, 1
Biogeographic traits, originally related to climate and/or soils

\begin{tabular}{|c|c|}
\hline $\begin{array}{l}\text { 11. Most Australian } \\
\text { Proteaceae have small } \\
\text { scleromorphic leaves, } \\
\text { occur under highly } \\
\text { seasonal climates in } \\
\text { 'open' vegetation, and } \\
\text { fossils can be traced to > } \\
70 \text { million years ago; } \\
\text { they also occur in } \\
\text { nutrient-impoverished }\end{array}$ & $\begin{array}{l}\text { Small leaves are an } \\
\text { adaptation to drought } \\
\text { and Proteaceae can be } \\
\text { traced to open, } \\
\text { Mediterranean-type } \\
\text { vegetation using } \\
\text { ancestral trait } \\
\text { assignment, poor soils } \\
\text { promoted diversification } \\
\text { of Proteaceae }\end{array}$ \\
\hline
\end{tabular}

12. Distribution,

Climate gradients have diversification and plant played a key role in and leaf size traits in the species diversification S African genus Protea and distribution of Cape shows strong correlation proteas, summer-rainfall with climatic gradients species have smaller in the Cape Floristic size, larger leaves
Onstein et

al. 2016,

Prentice et

al. 2017

Oldest Australian clades were fireprone at the time and long preceded a mediterranean climate; all species show fire adaptations essential for their survival and closed (forest) vegetation that share high flammability rather than high light or strong summer droughts
Fire adaptations were critical in th origin and diversification of the

Australian sclerophyllous Proteacea
(by ancestral trait assignment) long

before strong seasonality in the

Neogene and openness of vegetation in itself is not the critical constraint. 4,1
Lamont and $\mathrm{He}$ 2012, Pausas and

Lamont 2018
Mitchell et Coincident with climate change was a change in the fire al. 2018 regime, initiation of summer rainfall to the east and northeast in the Miocene produced grasslands that burn at 1-3 year intervals; all grassland proteas are nonserotinous an resprout after fire, frequently burnt plants will be smaller as frequently pruned by fire
Invasion of the grasslands was not possible until proteas evolved nonserotiny and the ability to resprout in response to frequent fire from

ancestors that were serotinous and firekilled (ancestral trait assignment). 4, 1
Lamont et al. 2013 Lamont et al. 2017

Province 
13. Distribution of chaparral species increased in Santa Rosa

Mountains, S California by $65 \mathrm{~m}$ from 1977 to 2007
The upward shift in species distribution can be attributed to a

warming climate (less snow, more rainfall variability) not air

pollution or increased fire frequency
Kelly and Goulden 2008 showed that the study sites had an elevational bias in fire history that led to lower levels of mortality in that period the higher altitudes so that there has been no altitudinal increase in distribution
The greater survival of $C$. greggii at the Schwilk and Keeley higher elevations was due to 2012 the last fire) not due to climate warming. 5, 1

Protective plant traits (biotic or abiotic)

\section{Terpenoids are abundant in palatable parts of some plant species and these deter consumption by herbivores}

\section{Thick bark is} protective against herbivore attack or water loss

\section{Terpenoids function to} deter herbivory

\section{Lawler et al. Terp}

prone species and are concentrated in highly exposed foliage; the associated species possess many fire-adapted traits, such as serotiny (leptospermoid Myrtaceae), thick bark (Eucalyptus), soil-stored seeds (Rutaceae); ineffective against many herbivores, e.g. koalas

Thick bark has evolved to deter herbivory and minimize water loss
Paine et al. Bark thickness is a function of fireproneness of the 2010, ecosystem; insulating properties of bark are (largely) a Pausas 2015 function of bark thickness; thick bark does not prevent infestation by bark beetles; exten of bark stripping not a function of bark thickness; species with thin bark may occur in deserts
Terpenoids are a flammability trait that Owens et al. 1998, is associated with strong fire adaptations of the host species that serves to increase fitness by reducing competition from less fire-tolerant species and ensures fire-adapted traits are expressed. 1,2

Thick bark is an adaptation for minimizing temperature rise at the

Vines 1968, Gill position of the cambium during the heat al. 2009, Brando et pulse from a fire; it may have other al. 2012, Pausas functions in non-fireprone systems. 4, 12015
16. Grasses with a blanket of dead leaves in adaptation for reducing savanna grasslands lack the likelihood of herbivory and survive herbivory and/or frost frost
Finckh et al. Dead leaves increase combustibility of the plant; savanna 2016, Mingo grasses are fire tolerant via soil-buried (heat-insulated) and Oesterheld 2009 buds; fireproneness long preceded the advent of recurren frost that is only present among upland grasslands; frost reduction will also benefit competing neighbours; fire recycles nutrients and opens up grasses to light
Dead leaves increase flammability of savanna grasses that reduces

competition from less heat-toleran Wakeling et al. 2012, Moore et al. eighbours and favours improvement in Paula 2019 growing conditions; soil-buried buds enabled fire survival long before the advent of recurrent frost (exaptation) 5,1 
17. Dead leaf and flower Dead leaf and flower retention in Banksia shrubs gives extra shade adaptation to reduce to stems and cones and summer drought renders them less desiccation and reduce exposed to borers and detection by predators granivores

18. Geophyty (shoots die back annually to underground storage structures with buds e. corms, bulbs, tubers) is associated with strongly seasonal climates, eg cold winters retention are an

He et al.

$$
2011
$$

Geophyty is an adaptation to environments with

seasonal temperature extremes with reliable growing season rainfal that enable the dormant plant to recover once the stress is over al. 2005 increase the likelihood of heat-induced follicle opening of serotinous cones and release of nutrients for recruitment of seedlings among fire-killed species; strong evolutionary association between dead leaf retention and nonsprouting, and flower retention and serotiny

Procheş et Geophyty is often associated with fireprone ecosystems that are also highly seasonal; the dead aboveground parts are highly flammable while the storage structures are insulated from fire heat; some geophytes evolved unde fireprone conditions preMiocene while frost-prone, seasonally dry conditions increased from the Miocene; many geophytes respond to fire by early flowering (protanthy) that takes advantage of postfire conditions for reproduction; some geophytes remain underground for many years until stimulated to shoot/flower by fire
Dead leaf and flower retention are an adaptation to enhance heat-induced follicle opening and seed release and nutrient availability when conditions for recruitment are optimal. 5, 1

Many geophytes are adapted to both highly seasonal and fireprone conditions (savannas, mediterranean) and both warmer or wetter conditions and fire may break bud dormancy and promote shoot growth and flowering. 3 ,
Low and Lamont 1990, He et al.

Lamont and Downes 2011, He et al. 2016, Pausas et al. 2018

\section{Traits associated with aridity}

\section{The Australian} grasstree, Xanthorrhoea has long thin leaves whose xeromorphic structure includes a thick cuticle, sunken stomates and bands of fibres

\section{Finely divided,} sclerophyllous foliage (many small leaves and branchlets per unit mass) is associated with drought-prone ecosystems
The structure and orientation of Xanthorrhoea leaves is designed to minimize transpirational water loss

Fahn 1954

\section{.}

Xanthorrhoea retains its pendulous leaves after death to form a dense 'skirt' around the caudex; both living and dead leaves are highly flammable and burn at $>1000^{\circ} \mathrm{C}$;

Xanthorrhoea survives the most intense of fires because mantle of non-ignitable leafbases; ignition releases ethylene that promotes fire-stimulated flowering; ignition melts the leafbase resin that then fills the airspaces
Dense, sclerophyllous foliage is an adaptation to climates with a hot dry summer that reduces water loss per unit mass mass 2003 and Wright 2003
Lamont et 2003 Wright

he

Species with finely divided, sclerophyllous foliage are abundant in fireprone vegetation; finely divided foliage is highly flammable; species with finely divided foliage possess other fire-adaptive traits such as resprouting, serotiny, soil-stored seeds; fire promotes the evolution of flammability traits.
The unique arrangement, structure and Lamont et al. 2004, retention of leaves in Xanthorrhoea is an Wittkuhn et al adaptation for maximizing its

flammability that reduces competition less fire-tolerant neighbours,
from

ensures flowering when recruitment conditions are favoured, and seals the caudex against stem damage by borers. 4,1

Dense, sclerophyllous foliage is highly combustible and serves to a) reduce competition from less fire-tolerant neighbours, and b) ensure advantage is

Burger and Bond 2015, Calitz et al. 2015, Pausas et al. 2012 as fire-stimulated resprouting, seed release and germination. 2, 2 
21. Leaf and stem succulence are associated with arid

climates and have

extremely low

transpiration rates
Succulence is an adaptation for

Lamont and Many succulents occur in fireprone vegetation; succulents

conserving water under 2000 survive fire as they are non-flammable and have a large

drought stress thermal mass when exposed to heat
Succulence is a fire-avoiding mechanism Calitz et al. 2015 that allows species in fireprone

vegetation to survive. 2,2 


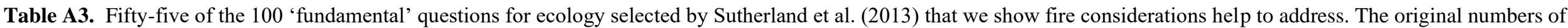
the questions have been retained. We have made no attempt to review the relevant literature but simply use the cited papers to illustrate how many of the questions have already been tackled.

\section{Fundamental ecological question \\ Examples of how the question has been, or can be, addressed in fireprone systems}

Evolutionary processes

1 What are the evolutionary consequences of species becoming less connected through fragmentation or more connected through globalization?

\section{How local is adaptation?}

4 What are the ecological causes and consequences of epigenetic variation?

5 What are the relative contributions of different levels of selection (gene, individual, group) to life-history evolution and the resulting population dynamics?
Increasing patchiness (fragmentation) of fires will deter long-distance dispersal of seeds (He et al. 2009) while many invasive species are fire-adapted, both suited for studying their evolutionary consequences.
Fire properties can be manipulated across the landscape to determine the limits of adaptation to fire of particular species

There are scores of fire byproducts in smoke and fire-heated air (eg methyl groups) that could be checked for their epigenetic properties and effects on plant fitness

The evolution of plant flammability is contentious, especially at what scale it operates. Elements of flammability are determined by genes (e.g., those controlling leaf area and mass, branching pattern, water content, volatile oils, dead biomass retention/ accumulation), it is manifested at the individual plant level (e.g., where dead biomass is located on the plant), and expressed at the community level (fuel structure in horizontal and vertical dimensions). The question can even be examined from the perspective of life-history evolution, population dynamics and community structure and function (Pausas and Keeley 2014)

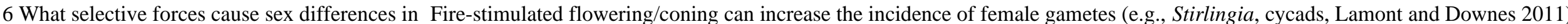
life history and what are their consequences for population dynamics?

8 How do the strength and form of density dependence influence feedbacks between population dynamics and life-history evolution?

9 How does phenotypic plasticity influence evolutionary trajectories?

10 What are the physiological bases of lifehistory tradeoffs?
Since germination is synchronized by fire, fireprone populations are ideal for studying seedling density effects that vary between microsite types and among resprouters/nonsprouters (Lamont et al. 1993)

Fire is a deterministic process, but it also has considerable stochastic properties, creating ample opportunity for the development of phenotypic plasticity. The divergence of the fire regime over geographic scales as a result of environmental and climatic variation; such phenotypic plasticity will take the evolution of relevant traits on different trajectories (He et al. 2019)

Resprouters (few seeds) and nonsprouters (many seeds) are ideal for studying the physiological basis of tradeoffs in seed set and seedling recruitment (Lamont and Wiens 2003, Pate et al. 1990, Bowen and Pate 2017) 
11 What are the evolutionary and ecological mechanisms that govern species' range margins?

13 How do species and population traits and landscape configuration interact to determine realized dispersal distances?

14 What is the heritability/genetic basis of dispersal and movement behaviour?

16 How do organisms make movement decisions in relation to dispersal, migration, foraging or mate search?

17 Do different demographic rates vary predictably over different spatial scales, and how do they then combine to influence spatiotemporal population dynamics?

18 How does demographic and spatial structure modify the effects of environmental

stochasticity on population dynamics?

19 How does environmental stochasticity and environmental change interact with density dependence to generate population dynamics and species distributions?

20 To what degree do trans-generational effects on life histories, such as maternal effects, impact on population dynamics?

21 What are the magnitudes and durations of carry-over effects of previous environmental experiences on an individual's subsequent life history and consequent population dynamics?
Fire regime interzones are well recognized as they are indicated by change in vegetation type. They are quite stable but can be manipulated by fire regime change so are ideal for studying control mechanisms

The patchy distribution of populations in fireprone landscapes, where fire may also prompt long-distance dispersal (LDD), makes this scenario ideal for such studies (e.g., LDD in Banksia, e.g., He et al. 2009)

The LDD traits of plant species in fireprone landscapes (e.g., wing load) are ideal for studies of their heritability (e.g., Merwin et al. 2012)

Plants cannot make decisions, but, from an evolutionary viewpoint, the varying patchiness of fires coupled with genotype parent assignment is ideal for studying dispersal and migration patterns and potential

Resprouters (few seeds) and nonsprouters (many seeds) are ideal contrasting life forms to study their demographic rates over varying spatial scales and how they influence spatiotemporal population dynamics in response to fire 
22 What causes massive variability in recruitment in some marine systems?

23 How does covariance among life-history traits affect their contributions to population dynamics?

24 What is the relative importance of direct (consumption, competition) vs. indirect

(induced behavioural change) interactions in

determining the effect of one species on others?

25 How important is individual variation to population, community, and ecosystem dynamics?

26 What demographic traits determine the resilience of natural populations to disturbance and perturbation?
There is also massive variability in fireprone systems due to the great range in fire properties and frequency

It is commonly observed that a specific fire regime selects for a suite of fire-related traits that allows plants to persist. e.g., serotiny and dead branch retention are coupled in pines (Schwilk and Ackerly 2001, He et al. 2012).

Fireprone systems are suitable for such studies and many interactions are triggered by fire such that interactions are affected by time since the last fire. Thus, the changing impact of plant species on other biota can be followed with time since fire

Many fireprone species vary phenotypically in different climates/vegetation types (He et al. 2018) so that their varying effects on dynamics at different scales can be assessed. Within population variation of individuals can also vary greatly (e.g., fecundity, phenology) with effects on the rate of hybridization receiving some study (Lamont et al. 2003)

Fireprone systems are ideal for the study of resistance and resilience, with contrasts available in the way seeds are stored and whole-plant responses to fire (Enright et al. 2014)

\section{Disease and Micro-organisms}

32 What is the relative importance of biotic vs. abiotic feedbacks between plants and soil for influencing plant growth?
Depleted soil nutrients over the long term create vegetation types that are adapted to infertile soils, and promote plants with highly flammable traits (e.g., small leaves, finely divided foliage, dead mass retention), and forming feedback cycles.

\section{Community dynamics and diversity}

39 How well can community properties and responses to environmental change be predicted from the distribution of simple synoptic traits, e.g. body size, leaf area?

42 How widespread and important are indirect interactions (e.g. apparent competition, apparent mutualism) in ecological communities?
Fire tolerance of species in fireprone systems (changing in intensity) can be predicted from their fire-related traits depending on the extent to which it has been shown that they increase fitness (Lamont and He 2017)

Many food webs and other interactions exist in fireprone systems and some of these are mediated by fire itself (Lamont 1994). Those that involve symbiotic microbes may be keystone (Lamont 1992) 
43 How do spatial and temporal environmental heterogeneity influence diversity at different scales?

44 How does species loss affect the extinction risk of the remaining species?

45 What is the relative importance of stochastic vs. deterministic processes in controlling

diversity and composition of communities, and how does this vary across ecosystem types?

46 How do we predict mechanistically how many species can coexist in a given area?

47 To what extent are local species composition and diversity controlled by dispersal limitation and the regional species pool?

48 What are the contributions of biogeographical factors and evolutionary history in determining present day ecological processes?

49 To what extent is primary producer diversity a driver of wider community diversity?

51 What is the relative importance of trophic and nontrophic interactions in determining the composition of communities?

52 How important are dynamic extinctionrecolonization equilibria to the persistence of species assemblages in fragmented landscapes?

53 Which mechanisms allow the long-term

Spatially and temporally varying fire events create spatial and temporal heterogeneity at different scales that affect alpha diversity and promote beta and gamma diversity (pyrodiversity begets biodiversity)

Fire can be the cause of species extinction (interval too long, too short) and the effect will depend on the level of species interactions and any keystone role they may have had (Lamont 1992)

Fire has strong stochastic properties but it can be treated as deterministic (fire at fixed intervals) in models and any differences in outcome can be explored (Enright et al. 1998). Stochasticity varies greatly under different fire regimes in different ecosystems

Fire-response traits of co-occurring species are well-known for particular ecosystems with some work on competitive sorting but these seem to have little impact on species spatial relations (Perry et al. 2017)

Fireprone systems are ideal to test this. Fire patchiness and the need for dispersal and recruitment to coincide with fire events help to quantify dispersal limitations (He et al. 2009).

Fire has been a potent evolutionary force since the 'fiery' Cretaceous when the major orders of flowering plants were evolving (He and Lamont 2018a) and will have had a profound effect on current ecological processes

Fire tolerance of primary producers will control their diversity and impact on other community biota

Trophic interactions can be controlled by the fire regime while simultaneous postfire recruitment heightens nontrophic interactions (Lamont et al. 1993)

Fire events can be manipulated to promote both extinction and recolonization (He et al., 2009); fires create temporal-spatially varying environmental heterogeneity - dynamic fragmented landscapes that provide a unique testing ground for persistence (Enright et al. 2014)

This question cannot be answered satisfactorily without considering fire. Fire, resprouting and variability of life history-disturbance coexistence of grasses and woody plants over a interactions are key to explaining long-term grass-tree coexistence in savannas (Higgins et al. 2000)

wide range of ecosystems? 
54 How do resource pulses affect resource use and interactions between organisms?

56 What is the feedback between diversity and diversification?
There is no better cause of a resource pulse than fire. Fire regulates resource availability in ecosystems across trophic levels, facilitating the maintenance of diverse communities in space and time. Fire releases nutrients that are locked up in biomass, creating resource pulses in the short term, promoting the dynamics of populations and species co-existence patterns across trophic levels (Bowman et al. 2016, Ponisio et al. 2016)

Fire is both a cause of extinction and force for trait innovation and proliferation and fireprone clades and regions are among the world's most speciose

\section{Ecosystem functioning}

58 Which ecosystems are susceptible to showing 'tipping' points and why?

59 How can we tell when an ecosystem is near a 'tipping' point?

60 Which factors and mechanisms determine the resilience of ecosystems to external perturbations and how do we measure resilience?

61 Which ecosystems and what properties are most sensitive to changes in community composition?

62 How is ecosystem function altered under realistic scenarios of biodiversity change?

66 How does spatial structure influence ecosystem function and how do we integrate within and between spatial scales to assess function?
Fireprone ecosystems should be one of the types of ecosystems susceptible to 'tipping' points. A certain vegetation type is maintained by a relatively fixed fire regime. A change in fire regime, especially as it interacts with increasing drought, could change ecosystem properties (Enright et al. 2014). However, some fire-response types, e.g., resprouters, are more persistent than others

Since fire properties (e.g. fire interval) are easily manipulated is should be possible to identify the community's 'tipping' point. Fire intervals are relatively stable over the long-term in a certain vegetation type. Ecosystems show clear symptoms in response to unprecedented fire events and intervals, providing a unique system to observe the approach of a 'tipping' point (Enright et al. 2014)

Fire might be considered an external perturbation in ecosystems normally considered fire-free (tundra, rainforest, desert); mechanisms of fire tolerance include postfire survival and recruitment as measures of resilience (Enright et al. 2014)

Fireprone ecosystems are sensitive to invasion by more fire-tolerant/flammable species. Invasive pines have altered natural fire regimes in South Africa through changes to the flammable biomass. Pines are larger than native plants and increase the fuel load and support more intense fires (Kraaij et al. 2018). In Australia, exotic grasses invade and outcompete the native ground flora (Milberg and Lamont 1995)

Invasion of a fireprone ecosystem by species with different fire-related traits provides the opportunity to examine any change in its function (Milberg and Lamont 1995). Research also shows that transition from relatively fire-free forests to fire-frequent savanna grasslands, as consequence of spreading C4 plants, completely changes ecosystem properties and function (van Langevelde et al. 2003)

Fire events vary horizontally (mosaics) and vertically (surface, canopy) that create spatial structure in environmental properties, and these spatial structures are dynamic as fire events also vary at temporal scales - dynamic environmental heterogeneity (He et al. 2019); thus, their effects on biodiversity and ecosystem function are readily assessed. Fire patchiness and time since fire affects the presence and movement of animals (Davies et al. 2018) 
68 To what extent is biotic invasion and native species loss creating ecosystems with altered properties?

70 Which, if any, species are functionally redundant in the context of stochastic or

directional environmental changes?

71 Is hysteresis the exception or the norm in ecological systems?

72 Can we predict the responses of ecosystems to environmental change based on the traits of species?
Fireprone ecosystems in South Africa and Australia are readily invaded by 'fireweeds' at the expense of native species (Milberg and Lamont 1995, Brooks et al. 2004) and this enables their functional effect to be measured. Invasions can affect native ecosystems by changing fuel properties that in turn affect fire behaviour and, ultimately, alter fire regime characteristics, such as frequency, intensity, extent, type, and seasonality of fire. If the regime change subsequently promotes dominance by the invaders, then an invasive plant-fire regime cycle is established.

Fire can be stochastic or directional (frequency change) so is an ideal tool to test functional redundancy

Hysteresis (fire history determines species diversity, structure and function) dictates ecology of fireprone ecosystems at any point in time

Fire-related traits can be used to model the effects of fire regime change on population viability (Enright et al. 1998)
Human impacts and global change

74 What is the role of evolution in recovery from exploitation and responses to other forms of relaxed selection?

76 What are the major feedbacks and interactions between the Earth's ecosystems and the atmosphere under a changing climate?

77 What are the key determinants of the future magnitude of marine and terrestrial carbon sinks?

78 How will atmospheric change affect primary production of terrestrial ecosystems?

81 How do natural communities respond to increased frequencies of extreme weather events predicted under global climate change?
Climate change is inducing fire regime change - how species are responding ultimately rather than proximately is subject to selection and diversification - there is some evidence of changes in genotype distribution within populations in response to drought, and the effect of increased fire (directional selection) and no fire (relaxed selection) is a suitable goal to explore as well (Lamont et al. 2019a)

A changing climate implies a change in the fire regime and thus in heat and gas transfers to the atmosphere and must be included in cycling models

Fires release enormous amounts of carbon into the atmosphere. Fire activity is predicted to increase with climate change. The increase in carbon dioxide as a result promotes plant growth and increases its role as a carbon sink but the rate is reduced by the incidence of fires (Goldammer et al. 2009).

Fire activity is predicted to increase with climate change. The increase in carbon dioxide as a result promotes plant growth and increases its role as a carbon sink but the rate is reduced by the incidence of fires throughout the Earth (Goldammer et al. 2009).

Extreme weather creates extreme fires. Much is known about the relationship between fire intensity and plant responses such as resprouting, seed release and germination but whole community responses has received little attention to extreme fire events, though the effect of increased fire frequencies has received some attention (Enright et al. 2014) 
82 In the face of rapid environmental change, what determines whether species adapt, shift their ranges or go extinct?
The innate tolerance/avoidance of species to various fire properties is well known, also their postfire seed dispersability - evidence for Banksias indicates that range shifts would be inadequate under predicted climate change while resprouters have a greater range and tolerance of climate change than nonsprouters (Witkowski and Lamont 2006, Merwin et al. 2012)

\section{Methods}

94 How is our understanding of ecology influenced by publication bias?

100 How can the feedbacks between human behaviour and ecological dynamics be accounted for in ecological models?
Papers on the $65 \%$ of the vegetated surface of Earth that is highly flammable are historically interpreted in terms of nondisturbance constraints, giving a biased view of nature (Pausas and Lamont 2018)

Much is known about human causes of, and responses to, fire events and the effects of different fire types on ecosystem dynamics, making fire ideal for feedback studies

\section{References for Tables A2 and A3 (unique from main text)}

Beaumont, K.P., Mackay, D.A. and M.A. Whalen. 2018. The role of Rhytidoponera metallica (Hymenoptera, Formicidae) in facilitating post-fire seed germination of three antdispersed legume species. Austral Ecology 43:128-138. CrossRef

Bertheau, C., Salle, A., Rossi, J-P., Bankhead-Dronnet, S., Pineau, X., Roux-Morabito, G., and F. Lieutiera. 2009. Colonisation of native and exotic conifers by indigenous bark beetles (Coleoptera, Scolytinae) in France. Forest Ecology and Management 258: 1619-1628. CrossRef

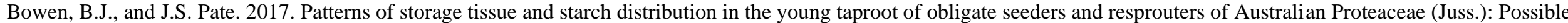
evidence of homoplastic evolution. Austral Ecology 42: 617-629. $\underline{\text { CrossRef }}$

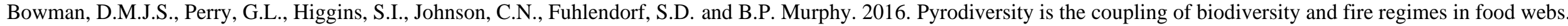
Philosophical Transactions of Royal Society B 371: 20150169. CrossRef

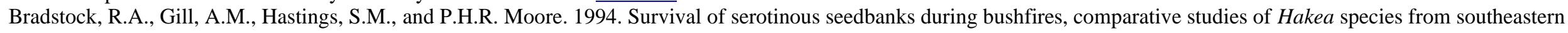
Australia. Australian Journal of Ecology 19: 276-282. CrossRef

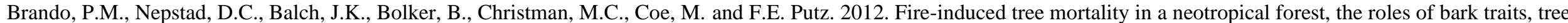
size, wood density, and fire behavior. Global Change Biology 18: 630-641. CrossRef

Brooks, M.L., D'antonio, C.M., Richardson, D.M., Grace, J.B., Keeley, J.E., et al. 2004. Effects of invasive alien plants on fire regimes. AIBS Bulletin 54: 677-688. CrossRef

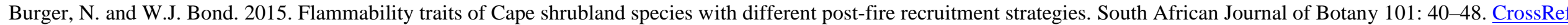

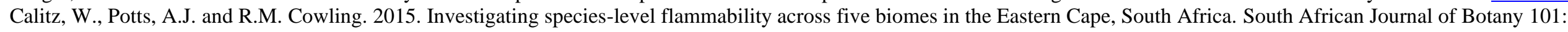
32-39. CrossRef

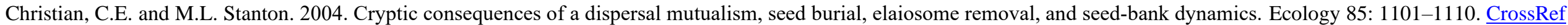

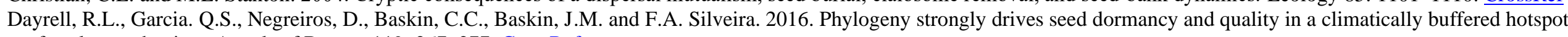
for plant endemism. Annals of Botany 119: 267-277. CrossRef

Enright, N.J., Marsula, R., Lamont, B.B., and C. Wissel. 1998. The ecological significance of canopy seed storage in fireprone environments, a model for nonsprouting shrubs. Journal of Ecology 86: 946-959. CrossRef 
Enright, N.J., Fontaine, J.B., Lamont, B.B., Miller, B.P., and V. Westcott. 2014. Resistance and resilience to changing climate and fire regime depend on plant functional traits. Journal of Ecology 102: 1572-1581. $\underline{\text { CrossRef }}$

Fahn, A. 1954. The anatomical structure of the Xanthorrhoeaceae Dumort. Botanical Journal of the Linnean Society 55: 158-184. CrossRef

Gill, R.M.A. 1992. A review of damage by mammals in north temperate forests, 1. Deer. Forestry 65: 145-169. CrossRef

Gómez, C., and X. Espadaler. 1998. Myrmecochorous dispersal distances, a world survey. Journal of Biogeography 25: 573-580. CrossRef

Groeneveld. J., Enright, N.J., Lamont, B.B., and C. Wissel. 2002. A spatial model of coexistence among three Banksia species along a habitat gradient in fireprone shrublands.

Journal of Ecology 90: 762-774. CrossRef

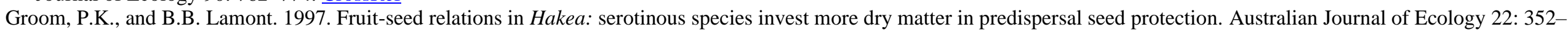
355. CrossRef

He, T., Lamont, B.B., and J.A. Manning. 2016. A Cretaceous origin for fire adaptations in the Cape flora. Scientific Reports 6: 34880. CrossRef

He, T., Lamont, B.B., Enright, N.J., D'Agui, H.M. and W.D. Stock. 2018. Environmental drivers and genomic architecture of trait differentiation among fire-adapted Banksia attenuata ecotypes. Journal of Integrative Plant Biology 61: 417-412. CrossRef

He, T., Lamont, B.B., Krauss, S.L., Enright, N.J., and B.P. Miller. 2009. Long-distance dispersal of seeds in the fire-tolerant shrub Banksia attenuata. Ecography 32: 571-580. CrossRef

Higgins, S.I., Bond, W.J., and W.S.W. Trollope. 2000. Fire, resprouting and variability, a recipe for grass-tree coexistence in savanna. Ecology 88: 203-229. CrossRef

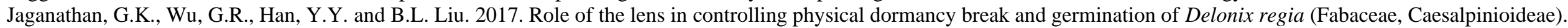
Plant Biology 19: 53-60. CrossRef

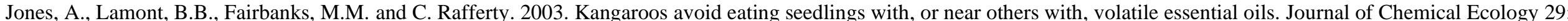
2621-2635. CrossRef

Kraaij, T., Baard, J.A., Arndt, J., Vhengani, L., and B.W. van Wilgen. 2018. An assessment of climate, weather, and fuel factors influencing a large, destructive wildfire in the Knysna region, South Africa. Fire Ecology 14: 4. CrossRef

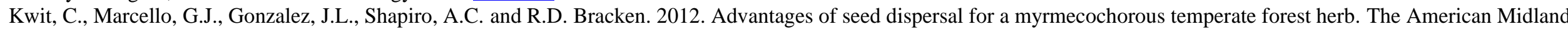
Naturalist 168: 9-18. CrossRef

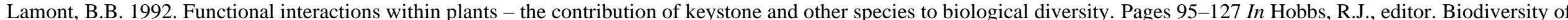
Mediterranean Ecosystems in Australia. Surrey Beatty, Sydney.

Lamont, B.B. 1994. Triangular trophic relationships in Mediterranean-climate Western Australia. Pages 83-89 In Arianoutsou, M. and Groves, R.H., editors. Plant-Animal Interactions in Mediterranean-type Ecosystems. Kluwer Academic, Dordrecht. CrossRef

Lamont, B.B. and N.J. Enright. 2000. Adaptive advantages of aerial seed banks. Plant Species Biology 15: 157-166. CrossRef

Lamont, B.B., and T. He. 2012. Fire-adapted Gondwanan Angiosperm floras arose in the Cretaceous. BMC Evolutionary Biology 12: 223. CrossRef

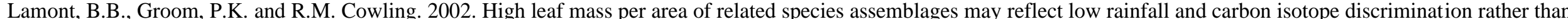
low phosphorus and nitrogen concentrations. Functional Ecology 16: 403-412. CrossRef

Lamont, B.B., Hanley, M.E., Groom, P.K., and T. He. 2016. Bird pollinators, seed storage and cockatoo granivores explain large woody fruits as best seed defense in Hakea. Perspectives in Plant Ecology, Evolution and Systematics 21: 55-77. CrossRef

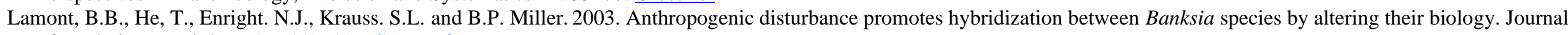
of Evolutionary Biology 16: 551-557. CrossRef

Lamont, B.B., Wittkuhn, R. and D. Korczynskyj. 2004. Ecology and ecophysiology of grasstrees. Australian Journal of Botany 52: 561-582. CrossRef

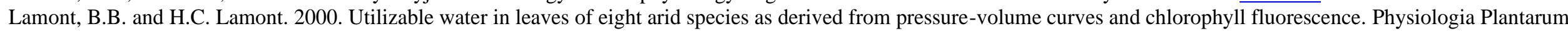
110: 64-71. CrossRef

Lawler, I.R., Foley, W.J., Eschler, B.M. and K. Handayde. 2000. Intraspecific variation in Eucalyptus secondary metabolites determines food intake by folivorous marsupials. 
Oecologia 116: 160-169. CrossRef

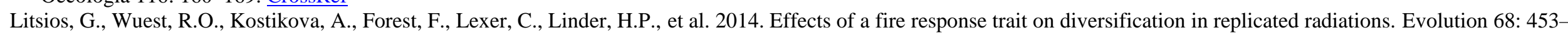
465. $\underline{\text { CrossRef }}$

Liyanage, G.S. and M.K. Ooi. 2017. Do dormancy-breaking temperature thresholds change as seeds age in the soil seed bank? Seed Science Research 27: 1-11. CrossRef López-Villalta, J.S. 2014. Trait-driven vs. syndrome-driven diversification in the Mediterranean. Ecologia Mediterranea 40: 27-33. CrossRef

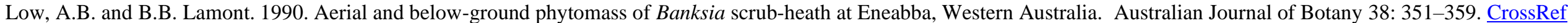

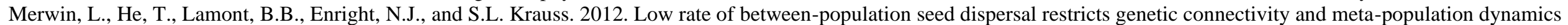
in a clonal shrub. PLoS ONE 7: e50974. CrossRef

Miller, A.D., and P. Chesson. 2009. Coexistence in disturbance-prone communities; how a resistance-resilience trade-off generates coexistence via the storage effect. The American Naturalist 173: E30-E43. CrossRef

Mingo, A., and M. Oesterheld. 2009. Retention of dead leaves by grasses as a defense against herbivores: A test on the palatable grass Paspalum dilatatum. Oikos 118: 753-757. CrossRef

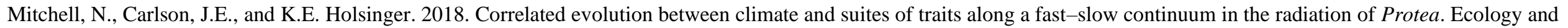
Evolution 8: 1853-1866. CrossRef

Moore, N.A., Camac, J.S., and J.W. Morgan. 2019. Effects of drought and fire on resprouting capacity of 52 temperate Australian perennial native grasses. New Phytologist 221 : 1424-1433. CrossRef

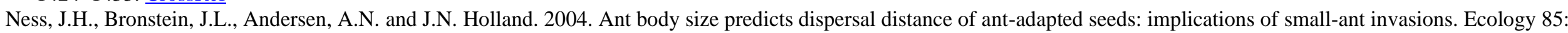
1244-1250. CrossRef

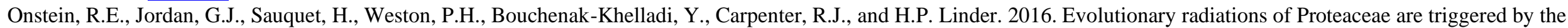
interaction between traits and climates in open habitats. Global Ecology \& Biogeography 25: 1239-1251. CrossRef

Ooi, M.K.J., Denham, A.J., Victor, M., Santana, V.M., and T. D. Auld. 2014. Temperature thresholds of physically dormant seeds and plant functional response to fire: variation among species and relative impact of climate change. Ecology and Evolution 4: 656-671. CrossRef

Owens, M.K., Lin, C-D., Taylor, C.A. Jr., and S.G. Whisenant. 1998. Seasonal patterns of plant flammability and monoterpenoid content in Juniperus ashei. Journal of Chemical Ecology 24: 2115-2129. CrossRef

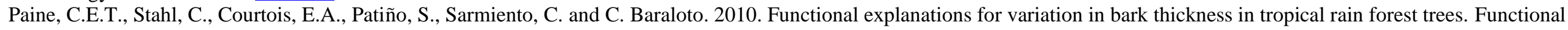
Ecology 24: 1202-1210. CrossRef

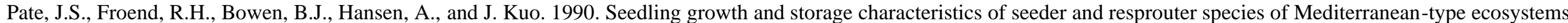
of SW Australia. Annals of Botany 65: 585-601. CrossRef

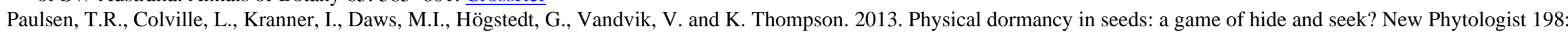
496-503. CrossRef

Pausas, J.G. 2015. Bark thickness and fire regime. Functional Ecology 29: 317-327. CrossRef

Pausas, J.G., Alessio, G.A., Moreira, B., and G. Corcobado. 2012. Fires enhance flammability in Ulex parviflorus. New Phytologist 193: 18-23. CrossRef

Pausas, J.G., Alessio, G.A., Moreira, B., and J.G. Segarra-Moragues. 2016. Secondary compounds enhance flammability in a Mediterranean plant. Oecologia 180: 103-110. CrossRef

Pausas, J.G. and S. Paula. 2019. Grasses and fire: the importance of hiding buds. New Phytologist 226(4): 957-959. CrossRef

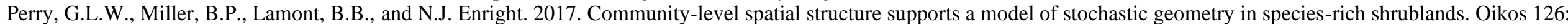
833-842. CrossRef

Ponisio, L.C., Wilkin, K., M'gonigle, L.K., Kulhanek, K., Cook, L., Thorp, R., et al. 2016. Pyrodiversity begets plant-pollinator community diversity. Global Change Biology 22: 1794-1808. CrossRef 
Prentice, E., Knerr, N., Schmidt-Lebuhn, A.N., González-Orozco, C.E., Bui, E.N., Laffan, S. and J.T. Miller. 2017. Do soil and climate properties drive biogeography of the Australian Proteaceae? Plant and Soil 417: 317-329. CrossRef

Procheş, S., Cowling, R.M., and D.R. du Preez. 2005. Patterns of geophyte diversity and storage organ size in the winter-rainfall region of southern Africa. Diversity and Distributions 11: 101-109. CrossRef

Raven, P.H., and D.I. Axelrod. 1978. Origin and Relationships of the California Flora, Vol. 72. San Diego, CA, University of California, pages 1-134.

Scheiter, S., Higgins, S.I., Osborne, C.P., Bradshaw, C., Lunt, D., Ripley, B.S., et al. 2012. Fire and fire-adapted vegetation promoted C4 expansion in the late Miocene. New Phytologist 195: 653-666. CrossRef

Soriano, D., Huante, P., Gamboa-deBuen, A., and A. Orozco-Segovia, A. 2014. Effects of burial and storage on germination and seed reserves of 18 tree species in a tropical deciduous forest in Mexico. Oecologia 174: 33-44. CrossRef

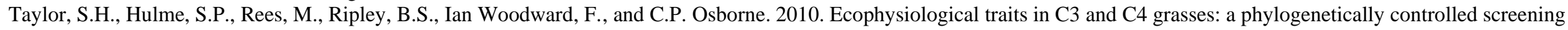
experiment. New Phytologist 185: 780-791. $\underline{\text { CrossRef }}$

van Langevelde F., van de Vijver, C.A.D.M., Kumar, L., van de Koppel, J., de Ridder, N., van Andel, J., et al. 2003. Effects of fire and herbivory on the stability of savanna ecosystems. Ecology 84: 337-350. CrossRef

Vines, R.G. 1968. Heat transfer through bark and the resistance of trees to fire. Australian Journal of Botany 16: 499-514. CrossRef

Wakeling, J.L., Cramer, M.D., and W.J. Bond. 2012. The savanna-grassland 'treeline', why don't savanna trees occur in upland grasslands? Journal of Ecology 100: 381-391. CrossRef

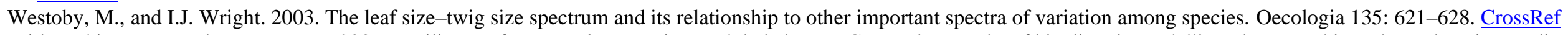

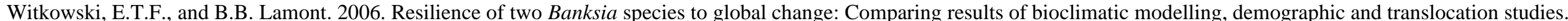
International Journal of Biodiversity Science and Management 2: 1-14. CrossRef

Wyse, S.V. and J.B. Dickie. 2018. Ecological correlates of seed dormancy differ among dormancy types: a case study in the legumes. New Phytologist 217: 477-479. CrossRef

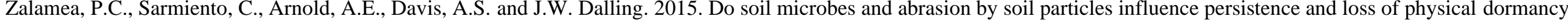
in seeds of tropical pioneers? Frontiers in Plant Science 5: 799. $\underline{\text { CrossRef }}$ 